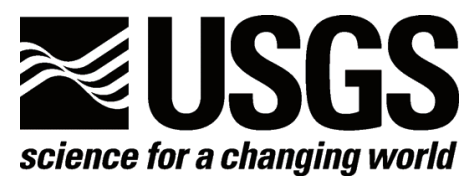

In cooperation with the Geological Survey of Bangladesh and Bangladesh Water Development Board

\title{
Compositional Data for Bengal Delta Sediment Collected from a Borehole at Rajoir, Bangladesh
}

By George N. Breit, James C. Yount, Md. Nehal Uddin, Ad. Atual Muneem, Heather A. Lowers, Cyrus J. Berry, and John W. Whitney

Open-File Report 2007-1022

U.S. Department of the Interior

U.S. Geological Survey 


\section{U.S. Department of the Interior \\ DIRK KEMPTHORNE, Secretary}

\section{U.S. Geological Survey \\ Mark D. Myers, Director}

U.S. Geological Survey, Reston, Virginia 2007

For product and ordering information:

World Wide Web: http://www.usgs.gov/pubprod

Telephone: 1-888-ASK-USGS

For more information on the USGS - the Federal source for science about the Earth, its natural and living resources, natural hazards, and the environment:

World Wide Web: http://www.usgs.gov

Telephone: 1-888-ASK-USGS

Suggested citation:

Breit, G.N., Yount, J.C., Uddin, Md. N., Muneem, Ad., A., Lowers, H.A., Berry, C.J., and Whitney, J.W., 2007, Compositional data for Bengal delta sediment collected from boreholes at Rajoir, Bangladesh: U.S.

Geological Survey Open-File Report 2007-1022.

Any use of trade, product, or firm names is for descriptive purposes only and does not imply endorsement by the U.S. Government.

Although this report is in the public domain, permission must be secured from the individual copyright owners to reproduce any copyrighted material contained within this report. 


\section{Contents}

Abstract

Introduction

Setting

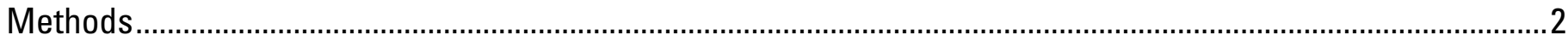

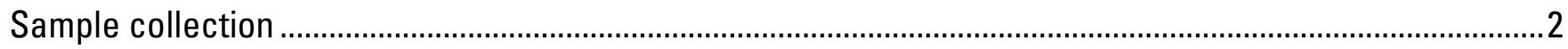

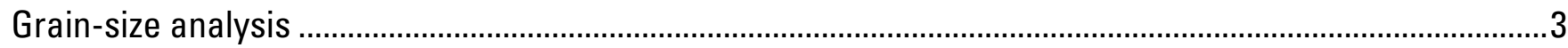

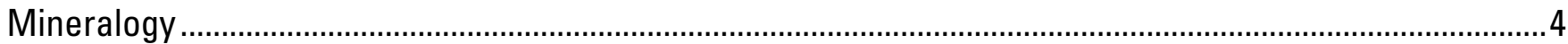

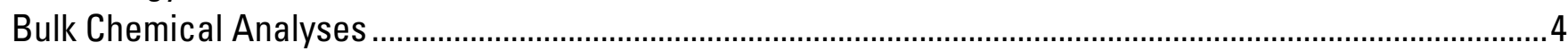

Chemical Extraction Analyses................................................................................................................

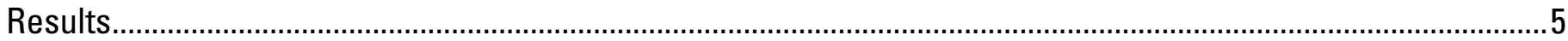

Physical and Mineralogic al Characteristics ………………................................................................

Bulk Chemical Composition .................................................................................................................

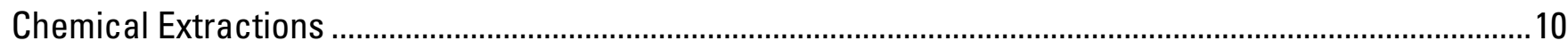

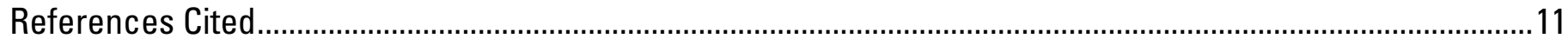

\section{Figures}

1. Location of Rajoir, Bangladesh ..............................................................................................................

2. Ternary diagram of sand, silt and clay abundances...................................................................................

3. Plot of potassium vs. barium in Rajoir sediment.........................................................................................

4. Comparison of measured and corrected sulfur concentrations ...................................................................

\section{Table}

1. Median, minimum, and maximum concentrations of chemical constituents.

\section{Appendices}

1. Depth and description of air-dried sediment samples ................................................................................

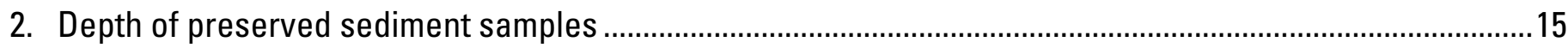

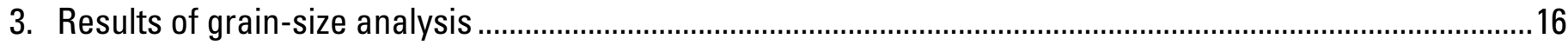

4. Major minerals present in air-dried sediment samples as determined by $X$-ray diffraction...........................17

5. Results of quantitative mineralogical analysis of air-dried sediments using $X$-ray diffraction ......................18

6. Results of carbon and sulfur analysis of air-dried samples.......................................................................19

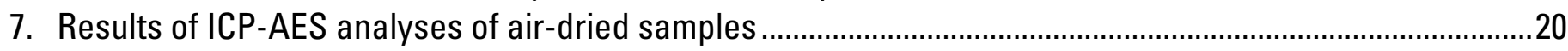

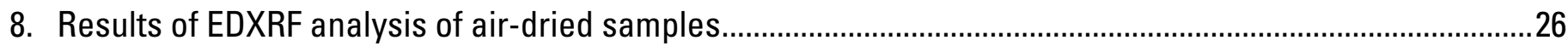

9. Results of arsenic analyses by HGAAS of air-dried samples........................................................................

10. Total iron and ferrous iron extracted by $0.5 \mathrm{~N} \mathrm{HCl}$ from preserved sediment samples ...................................33

11. Results of analyses of $0.5 \mathrm{~N} \mathrm{HCl}$ extract solutions from preserved sediment samples ...................................

12. Concentrations of acid-volatile sulfide, reducible sulfide and acid-soluble sulfate.......................................40 
SI to Inch/Pound

\begin{tabular}{|c|c|c|}
\hline Multiply & By & To obtain \\
\hline \multicolumn{3}{|l|}{ Length } \\
\hline centimeter $(\mathrm{cm})$ & 0.3937 & inch (in.) \\
\hline millimeter $(\mathrm{mm})$ & 0.03937 & inch (in.) \\
\hline meter $(\mathrm{m})$ & 3.281 & foot $(\mathrm{ft})$ \\
\hline kilometer $(\mathrm{km})$ & 0.6214 & mile (mi) \\
\hline kilometer $(\mathrm{km})$ & 0.5400 & mile, nautical (nmi) \\
\hline meter $(\mathrm{m})$ & 1.094 & yard (yd) \\
\hline \multicolumn{3}{|l|}{ Volume } \\
\hline milliliter & 0.03382 & ounce, fluid (fl. oz) \\
\hline milliliter & 0.002113 & pint $(\mathrm{pt})$ \\
\hline milliliter & 0.001057 & quart (qt) \\
\hline milliliter & 0.06102 & cubic inch $\left(\mathrm{in}^{3}\right)$ \\
\hline \multicolumn{3}{|l|}{ Mass } \\
\hline $\operatorname{gram}(\mathrm{g})$ & 0.03527 & ounce, avoirdupois (oz) \\
\hline kilogram (kg) & 2.205 & pound avoirdupois (lb) \\
\hline \multicolumn{3}{|c|}{$\begin{array}{l}\text { Temperature in degrees Celsius }\left({ }^{\circ} \mathrm{C}\right) \text { may be converted to degrees Fahrenheit }\left({ }^{\circ} \mathrm{F}\right) \text { as follows: } \\
{ }^{\circ} \mathrm{F}=\left(1.8 \times{ }^{\circ} \mathrm{C}\right)+32 \\
\text { Temperature in degrees Fahrenheit }\left({ }^{\circ} \mathrm{F}\right) \text { may be converted to degrees Celsius }\left({ }^{\circ} \mathrm{C}\right) \text { as follows: } \\
{ }^{\circ} \mathrm{C}=\left({ }^{\circ} \mathrm{F}-32\right) / 1.8 \\
\text { Horizontal coordinate information is referenced to World Geodetic Svstem } 1984 \text { (WGS 84) }\end{array}$} \\
\hline
\end{tabular}




\section{Chemical Symbols}

\begin{tabular}{|c|c|}
\hline Abbreviation & Chemical Species \\
\hline $\mathrm{Ag}$ & silver \\
\hline $\mathrm{Al}$ & aluminum \\
\hline As & arsenic \\
\hline $\mathrm{Au}$ & gold \\
\hline $\mathrm{B}$ & boron \\
\hline $\mathrm{Ba}$ & barium \\
\hline $\mathrm{Be}$ & beryllium \\
\hline $\mathrm{Bi}$ & bismuth \\
\hline $\mathrm{C}$ & carbon \\
\hline C-total & total carbon \\
\hline C-carbonate & carbonate carbon \\
\hline $\mathrm{Ca}$ & calcium \\
\hline $\mathrm{Cd}$ & cadmium \\
\hline $\mathrm{Ce}$ & cerium \\
\hline $\mathrm{Co}$ & cobalt \\
\hline $\mathrm{Cr}$ & chromium \\
\hline $\mathrm{Cu}$ & copper \\
\hline $\mathrm{Cs}$ & cesium \\
\hline $\mathrm{Eu}$ & europium \\
\hline $\mathrm{Fe}$ & iron \\
\hline $\mathrm{Ga}$ & gallium \\
\hline $\mathrm{Ge}$ & germanium \\
\hline Ho & holmium \\
\hline $\mathrm{K}$ & potassium \\
\hline $\mathrm{La}$ & lanthanum \\
\hline $\mathrm{Li}$ & lithium \\
\hline $\mathrm{Mg}$ & magnesium \\
\hline $\mathrm{Mn}$ & manganese \\
\hline Mo & molybdenum \\
\hline $\mathrm{Na}$ & sodium \\
\hline $\mathrm{Nb}$ & niobium \\
\hline $\mathrm{Nd}$ & neodymium \\
\hline $\mathrm{Ni}$ & nickel \\
\hline $\mathrm{P}$ & phosphorous \\
\hline $\mathrm{Pb}$ & lead \\
\hline $\mathrm{Rb}$ & rubidium \\
\hline $\mathrm{S}$ & sulfur \\
\hline $\mathrm{Sb}$ & antimony \\
\hline $\mathrm{Sc}$ & scandium \\
\hline $\mathrm{Se}$ & selenium \\
\hline $\mathrm{SiO}_{2}$ & silicon dioxide (silica) \\
\hline $\mathrm{Sn}$ & $\operatorname{tin}$ \\
\hline $\mathrm{Sr}$ & strontium \\
\hline
\end{tabular}


Ta

Th

Ti

U

$\mathrm{V}$

W

$\mathrm{Y}$

$\mathrm{Yb}$

$\mathrm{Zn}$

$\mathrm{Zr}$ tantalum

thorium

titanium

uranium

vanadium

tungsten

yttrium

ytterbium

zinc

zirconium 


\title{
Compositional Data for Bengal Delta Sediment Collected from a Borehole at Rajoir, Bangladesh
}

\author{
By George N. Breit, James C. Yount, Md. Nehal Uddin, Ad. Atual Muneem, Heather A. Lowers, Cyrus \\ J. Berry, and John W. Whitney
}

\begin{abstract}
Processes active within sediment of the Bengal basin have attracted world concern because of the locally high content of arsenic dissolved in ground water drawn from that sediment. Sediment samples were collected from a borehole in the town of Rajoir, Rajoir upazila, Madaripur district, Bangladesh, to investigate the processes contributing to arsenic contamination. The samples were mineralogically and chemically analyzed to determine compositional variations related to the arsenic content of the sediment. Mineralogy of the sediment was determined using powder X-ray diffraction. Bulk chemical composition was measured by Combustion; Inductively Coupled Plasma Atomic Emission Spectroscopy; Energy Dispersive X-ray Fluorescence; and Hydride Generation Atomic Absorption Spectrophotometry. Sediment was treated with $0.5 \mathrm{~N} \mathrm{HCl}$ and resulting solutions were analyzed, primarily to evaluate the abundance and oxidation state of acidsoluble iron. Acid-volatile sulfide, acid-soluble sulfate, and reducible sulfide were also measured on a few samples. Sediment sampled at Rajoir is typically unlithified, gray, micaceous, feldspathic arenaceous sand with a few silt and clay layers. Arsenic content of the sediment ranges from 0.6 to $21 \mathrm{ppm}$ with a median of $1.2 \mathrm{ppm}$.
\end{abstract}

\section{Introduction}

The ingestion of arsenic-rich ground water was first proposed as the cause for a range of health problems experienced by residents of the Bengal basin in India in 1983 (Gorair and others, 1984; Saha, 1984; 1995). Subsequent testing of wells across the basin has determined that ground water locally contains high concentrations of arsenic. An estimated 40 million residents $(20 \%$ of the population) consume water that exceeds the local arsenic drinking water standard of $50 \mu \mathrm{g} / \mathrm{L}$ (World Bank, 2005). In addition, this contaminated water is used to irrigate agricultural land needed to supply food for an increasing population. Explanations for the contamination have generally proposed that naturally occurring arsenic is released from ferric oxyhydroxide grain coatings in response to microbially facilitated reduction in the subsurface (Nickson and others, 2000; Smedley and Kinniburgh, 2002; Harvey and others, 2002; Horneman and others, 2004; Ravenscroft and others, 2005). This report presents the results of characterization of sediment samples in south-central Bangladesh within the town of Rajoir (fig. 1).

A primary concern for aid agencies that seek to alleviate the health crisis caused by the consumption of arsenic-rich water is to identify methods to supply safe drinking water. One of the proposed mitigation strategies is to install water wells to depths below $150 \mathrm{~m}$. Water analyses 
summarized in the National Arsenic Mitigation Information Center (NAMIC) and other databases (www.bamwsp.org) show that the frequency of wells that produce water exceeding the drinking water standard decrease with increasing depth. Although the lack of arsenic in water produced by these deeper wells has been attributed to removal of arsenic in the sediment by ground-water flow, no evidence has been offered to verify the loss of arsenic. This investigation determined the composition of sediment from depths as great as 450 meters to provide the data to support an evaluation of the viability of deeper aquifers to sustain production of water with low arsenic contents. Funding support for USGS work on this project was provided by the U.S. Agency for International Development.

\section{Setting}

The village of Rajoir is located approximately 65 kilometers southwest of the capital city of Dhaka in Rajoir upazila, Madaripur District (fig. 1). Testing of 13,000 tubewells in the Rajoir upazila determined that more than $75 \%$ produce water containing dissolved arsenic concentrations greater than $50 \mu \mathrm{g} / \mathrm{L}$ (www.bamwsp.org). Rajoir is $50 \mathrm{~km}$ west of the Meghna Estuary, which is currently the principal discharge for the Ganges, Brahmaputra, and Meghna River drainage basins, and 35 $\mathrm{km}$ south of the Padma River (Ganges). The borehole site is located on the Ganges floodplain near the Gopalganj beel (a shallow ephemeral lake characterized by carbonaceous sediment) (Brammer, 1996). Much of the sediment transported by the rivers and deposited in the basin originates in crystalline rocks of the high Himalayas, with lesser additions from the Indian Shield to the west, the Shillong Plateau to the north, and Tertiary-age sedimentary rocks that are exposed in the foothills to the Himalayas. The Tertiary rock is composed mostly of sediment originally shed from the ancestral Indian Shield and early Himalaya uplift, which was buried along the paleo-Indian continental margin, lithified, and tectonically uplifted into the weathering zone during the IndiaAsia collision. Holocene sediment accumulation rates for the Bengal delta range up to $1 \mathrm{~cm}$ per year as a result of the large amount of sediment transport, sea level rise, and accommodation space created by subsidence (Goodbred and Kuehl, 2000).

\section{Methods}

\section{Sample Collection}

Sediment samples were collected from a borehole by coring selected depth intervals during the spring and summer of 2004. The borehole was drilled by the Geological Survey of Bangladesh (GSB); borehole SH-2 was located at $23.205483^{\circ} \mathrm{N}$ latitude and $90.069361^{\circ} \mathrm{E}$ longitude (WGS84 datum) and was drilled to a total depth of 450 meters. Drilling fluid used by the GSB was a mix of water and bentonite with the addition of barite when drilling advanced below approximately $230 \mathrm{~m}$ depth. Thirty-seven samples of sediment were collected from the $450 \mathrm{~m}$ borehole at approximately $10 \mathrm{~m}$ intervals. Recovered sediment was described in the field (Appendix 1). Bulk samples were air-dried prior to analysis and are designated as -AD in the appendices.

Aliquots of each sample were placed in glass vials filled with argon gas at the drill site to preserve the oxidation state of iron and arsenic. These preserved samples are identified as $-\mathrm{P}$ in subsequent tables. Some preserved samples were collected at slightly different depth intervals than the $-\mathrm{AD}$ samples, as listed in Appendix 2. Preserved samples were collected using a detipped $10 \mathrm{~mL}$ syringe that was used to extract the sediment recovered in the lowest section of the core barrel (immediately above the coring bit). This material was considered to be the least contaminated by 
drilling fluid. The sediment collected in the detipped syringe was then transferred to an amber glass vial equipped with a Teflon-coated septum. Sediment was transferred into the vial while the vial was purged with flowing argon gas. The vial was capped and flushed with additional argon for five minutes using needles to introduce and vent the gas through the septum. After purging with the gas, the vial was frozen until shipment to the United States. During shipment the vials thawed but remained sealed; they were promptly refrozen upon arrival at the USGS laboratories.

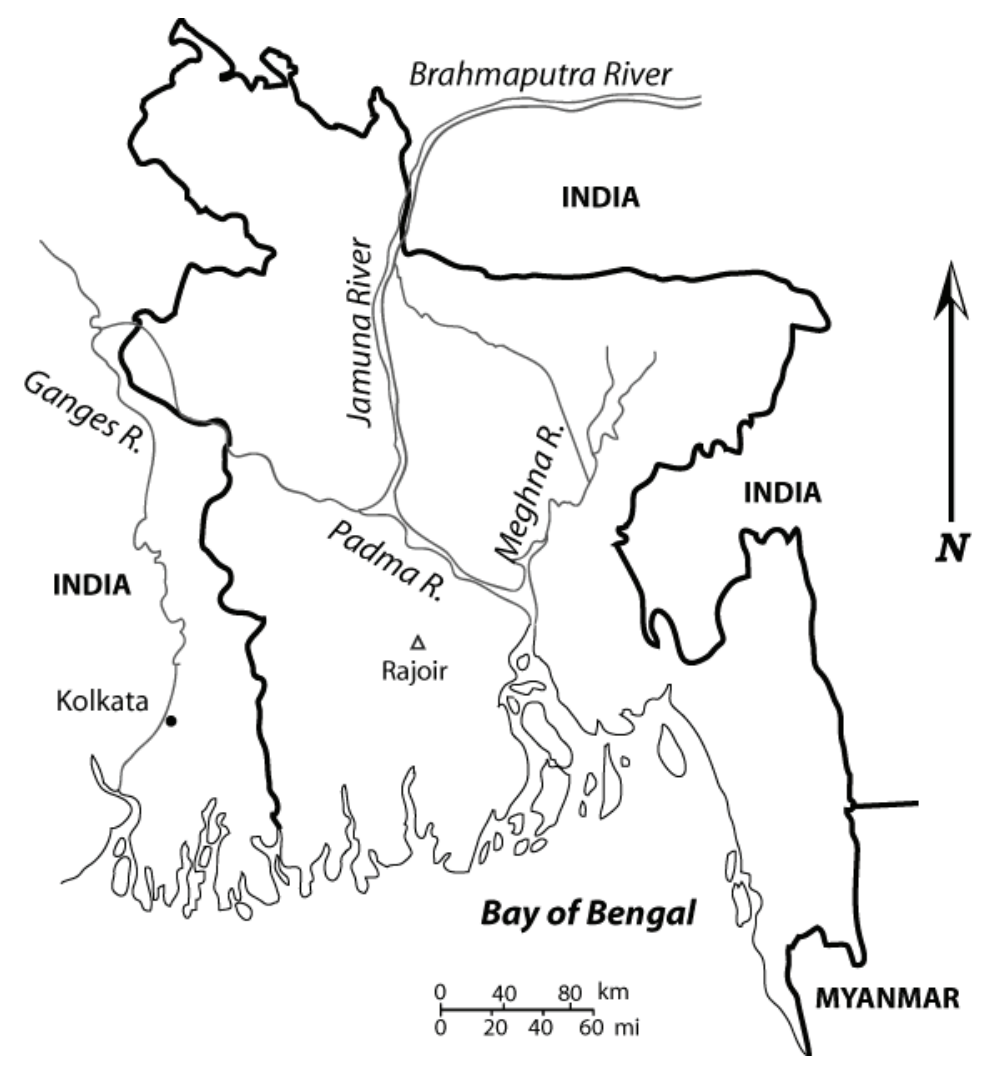

Figure 1. Map showing the location of the Rajoir study site in south-central Bangladesh.

\section{Grain-size Analysis}

Aliquots of the bulk sediment samples were analyzed to determine grain size using a Malvern Mastersizer S long bed laser refraction instrument. Approximately 3 gram splits of sediment were soaked overnight in $40 \mathrm{~mL}$ of distilled water amended with $20 \mathrm{~mL}$ of 0.25 weight percent sodium hexametaphosphate to enhance particle disaggregation and dispersion. Consistent with the observed lack of cementation, Rajoir sediment samples dispersed easily. Grain-size characteristics of the samples are presented in Appendix 3.

\section{Mineralogy}

To determine the major mineral phases in the sediment, splits of 37 bulk samples were ground to < $50 \mu \mathrm{m}$ (micrometer) in an agate shatterbox prior to analysis by X-ray diffraction. Side-packed 
mounts were prepared by loading the powdered sample against frosted glass to minimize preferential orientation. The mounts were analyzed using Ni-filtered, $\mathrm{Cu} \mathrm{K} \alpha$ radiation on a Siemens D500 equipped with a graphite monochromater. Samples were scanned from 4 to 64 degrees $2 \theta$ with a 0.02 degree step size and count time of 2 seconds per step.

Ten samples were prepared according to the methods described in Eberl (2002) for quantitative mineral analysis. This method requires micronizing the sample with $\mathrm{ZnO}$ as an internal standard. The ROCKJOCK (Eberl, 2002) program was then used to calculate the abundance of major mineral constituents. Analytical precision of the ROCKJOCK method is estimated to be within ten relative percent. Results of the qualitative and quantitative XRD analyses are listed in Appendices 4 and 5.

\section{Bulk Chemical Analyses}

Air-dried samples were analyzed to determine chemical composition by Combustion; Inductively Coupled Plasma Atomic Emission Spectroscopy (ICP-AES); Energy Dispersive X-ray Fluorescence (EDXRF); and Hydride Generation Atomic Absorption Spectrophotometery (HGAAS). All samples were homogenized using a mortar and pestle, then split and ground in an agate shatterbox prior to analysis. The combustion procedure of Brown and Curry (2002a, 2002b) determined the total carbon and sulfur concentrations. Carbonate carbon was measured by evolution of carbon dioxide using the Chittick method (Dreimanis, 1962). Samples analyzed by ICP-AES were first dissolved using the four acid digestion as described in Briggs (2002). ICPAES determined the concentration of 40 elements. EDXRF analyses followed the procedure of Siems (2002) in which a pressed powder mount was analyzed directly for 30 elements. Arsenic concentrations were also obtained using HGAAS according to the method of Hageman and others (2002). HGAAS was used as an additional technique to measure arsenic content because of its lower detection limit, and higher precision and accuracy. Results of the chemical analyses of the bulk samples are listed in Appendices 6 though 9.

Precision of duplicate splits of the same sample were within 10 relative percent for elements with concentrations greater than 3 times the detection limit for Combustion, Chittick, ICP-AES, and EDXRF methods. Elements present in lower concentrations were reproduced within 30 relative percent. Duplicate total arsenic measurements by HGAAS were consistently within 4 relative percent. Analyses of solid and rock standards submitted with the samples yielded results within the precision and accuracy described in Taggart (2002).

\section{Chemical Extraction Analyses}

Selected sediment samples were treated with $0.5 \mathrm{~N} \mathrm{HCl}$ primarily to determine the oxidation state and abundance of acid-soluble iron. A 3 to 5 gram aliquot of each of the 37 frozen, preserved sediment samples was transferred to an acid-washed amber serum vial under flowing high-purity nitrogen. The sediment was exposed to air for a few minutes during the transfer, but experiments determined that a minimum of 30 minutes of exposure of the cold sediment was needed before iron oxidation was detectable in the extract solutions. Forty $\mathrm{mL}$ of $0.5 \mathrm{~N}$ hydrochloric acid was added; the vial was sealed with a rubber septum, purged with nitrogen gas, wrapped with aluminum foil, and shaken periodically. Following 24 hours, $30 \mathrm{~mL}$ of the acid solution was withdrawn through the septum and filtered through a $0.2 \mu \mathrm{m}$ syringe filter. An aliquot of the solution was immediately analyzed to determine the concentration of dissolved ferrous iron and dissolved total iron using the Orthophenanthroline method (Clesceri and others, 1998) (Appendix 10). A second aliquot of the remaining solution was analyzed by ICP-AES for 25 elements and for arsenic by HGAAS. Results 
of the analyses are presented in Appendices 10 and 11. Measured concentrations of extractions with $0.5 \mathrm{~N} \mathrm{HCl}$ of replicate samples of the sediment typically reproduced within 15 percent, but ratios of ferrous to total extractable iron were reproduced within 3 percent. Variations in element concentrations in the replicates are attributed to sample heterogeneity.

The abundances of acid-volatile sulfide (AVS), acid-soluble sulfate, and reducible sulfide (DI), which is mainly pyritic sulfur, were determined following the extraction scheme of Tuttle and others (1986). Sulfur speciation was determined on a 2 to 5 gram aliquot of preserved sediment that was transferred while only partially thawed into the reaction vessel. Under flowing nitrogen, the sample was combined with $80 \mathrm{~mL}$ of $6 \mathrm{~N} \mathrm{HCl}$ that contained 2 grams of stannous chloride $\left(\mathrm{SnCl}_{2}\right)$. The $\mathrm{SnCl}_{2}$ was added to reduce ferric iron in the samples that might oxidize evolved hydrogen sulfide $\left(\mathrm{H}_{2} \mathrm{~S}\right)$ in the reaction vessel (Rice and others, 1993). After 15 to 30 minutes, the reaction vessel was heated to boiling to increase the reaction rate. The evolved $\mathrm{H}_{2} \mathrm{~S}$ was carried in flowing nitrogen through a reservoir of buffer solution $(\mathrm{pH} 4)$ to remove $\mathrm{HCl}$ and bubbled through a trap containing $1 \mathrm{~N}$ silver nitrate $\left(\mathrm{AgNO}_{3}\right)$ until the reaction was complete. The resulting silver sulfide $\left(\mathrm{Ag}_{2} \mathrm{~S}\right)$ was collected by filtration, air-dried, and weighed to measure the abundance of AVS. The acid solution was separated from the residual solid by filtration, and the residual solid was air-dried and weighed. The acid solution was reacted with $10 \mathrm{~mL}$ of $10 \%$ barium chloride to precipitate dissolved sulfate as barium sulfate, which is considered acid-soluble sulfate. The residual sediment from the AVS extraction was placed in a reaction vessel under flowing nitrogen and combined with $50 \mathrm{~mL}$ of $1 \mathrm{M}$ chromous chloride $\left(\mathrm{CrCl}_{2}\right)$ in $4 \mathrm{~N} \mathrm{HCl}$ containing 10 milliliters of ethanol. Chromium (II) converts reducible sulfide minerals (i.e., pyrite) to $\mathrm{H}_{2} \mathrm{~S}$. The $\mathrm{H}_{2} \mathrm{~S}$ is transferred to a $1 \mathrm{~N} \mathrm{AgNO}_{3}$ trap as described for the AVS extraction. The solution is boiled for approximately 1 hour or until evolution of $\mathrm{H}_{2} \mathrm{~S}$ has stopped. Results of the sulfur speciation are listed in Appendix 12.

\section{Results}

\section{Physical and mineralogical characteristics}

Sediment samples from the Rajoir borehole are typically gray and range from silty clay to pebbly sand. The relative grain size distribution of the sample materials from the borehole are plotted in Figure 2. XRD analyses identified quartz as the major constituent of the sediment with minor amounts of plagioclase, potassium feldspar, mica, chlorite, and amphiboles (Appendices 4 and 5). Confirmed authigenic phases detected by XRD in a few samples include siderite and pyrite; calcite was not detected in any of the samples. 


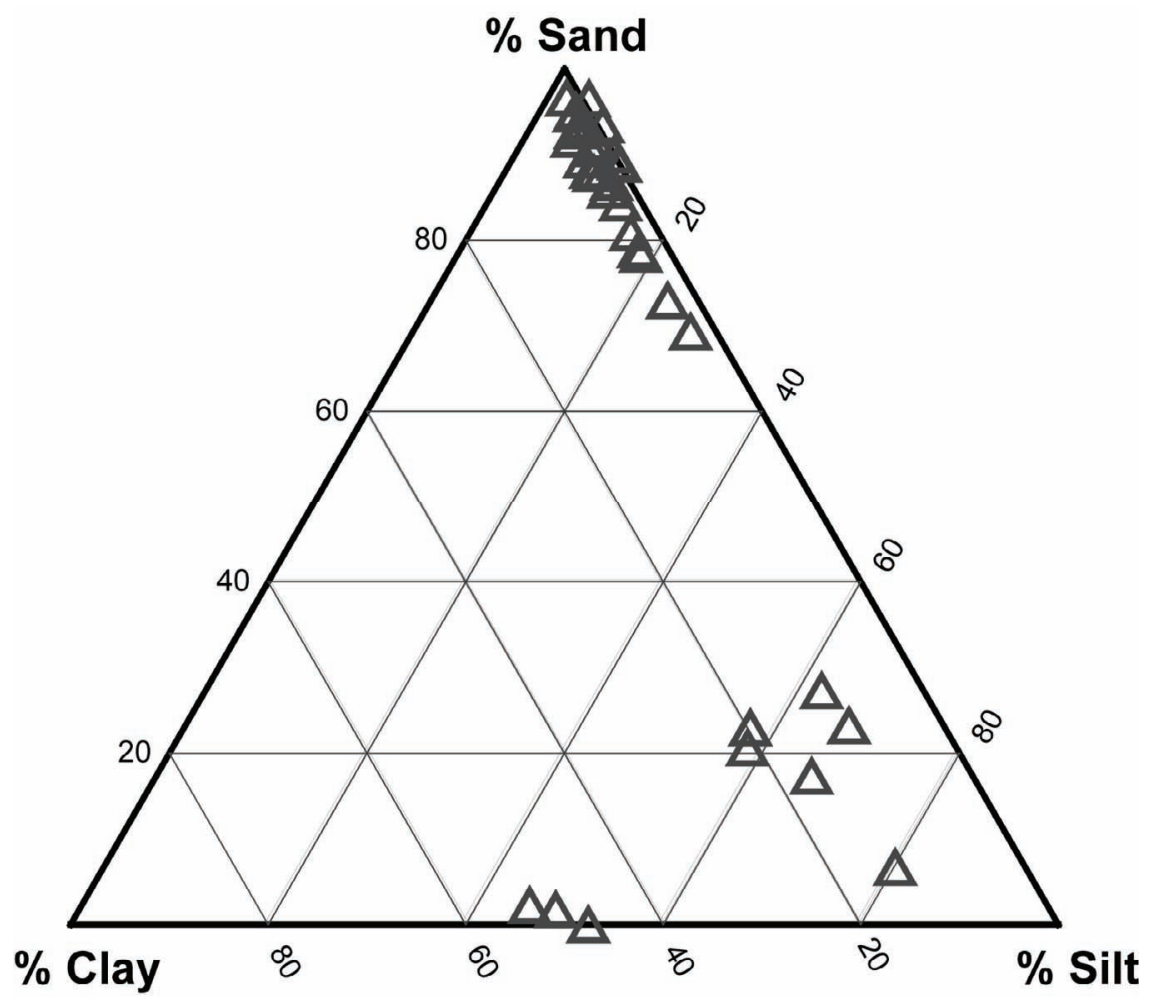

Figure 2. Ternary diagram of results of grain size analyses (Appendix 3 ) in sediment samples recovered from the borehole at Rajoir, Bangladesh.

\section{Bulk Chemical Composition}

The median, minimum, and maximum concentrations of chemical constituents measured in bulk air-dried sediment from the SH-2 borehole are listed in Table 1. Compared to the sediment analyzed from the Srirampur borehole located approximately $70 \mathrm{~km}$ east of the current study site (Breit and others, 2006), Rajoir sediment has lower contents of arsenic, organic carbon, and sulfur. Total arsenic concentrations of the Rajoir sediment range from 0.6 to $21 \mathrm{ppm}$ based on the HGAS analyses.

Unusually high concentrations of barium (>500 ppm) were detected in sediment collected below depths of approximately 230 meters. The drilling engineer reported that $230 \mathrm{~m}$ was the depth at which barite was added to the drilling fluid to prevent potential blowouts. Because sulfur is an important component of the processes active within the sediment, the following procedure was used to correct sulfur concentrations based on the excess barium content.

Potassium and barium have a recognized geochemical association in potassium feldspars and micas (Puchelt, 1978), which are the most common residence of barium in sediments. This association is evident in the sediment collected at Rajoir and elsewhere in Bangladesh (Breit and others, 2006). Samples recovered from depths less than 230 meters (uncontaminated with barite) have a strong correlation of barium with potassium $\left(r^{2}=0.9\right.$; fig. 3$)$. The amount of excess barium in the deeper 
samples was then calculated based on the amount of barium expected for the measured amount of potassium (equation 1). Because of the uncertainty in the analytical data and the deviation from an ideal relation between $\mathrm{Ba}$ and $\mathrm{K}$, only samples with greater than $200 \mathrm{ppm}$ excess barium were considered to have sufficient contamination to merit correction. In addition, barium contents of $200 \mathrm{ppm}$, if contained in barite, would correspond to approximately 0.005 weight percent sulfur, which is close to the detection limit for sulfur analyses. Accordingly, sulfur concentrations in the samples were corrected using equation 2 . Results of the recalculation of sulfur concentration are plotted in Figure 4. Note that the high sulfur concentrations detected in the samples are unaffected by the barite correction.

$$
\mathrm{Ba}(\mathrm{ppm}) \text { excess }=\mathrm{Ba}(\mathrm{ppm}) \text { measured }-(170 * \mathrm{~K}(\mathrm{wt} . \%)+60)
$$

$$
\text { Sulfur (wt.\%) corrected }=\text { Sulfur (wt.\%) measured }-(0.233 * \mathrm{Ba}(\mathrm{wt} . \%) \text { excess })
$$

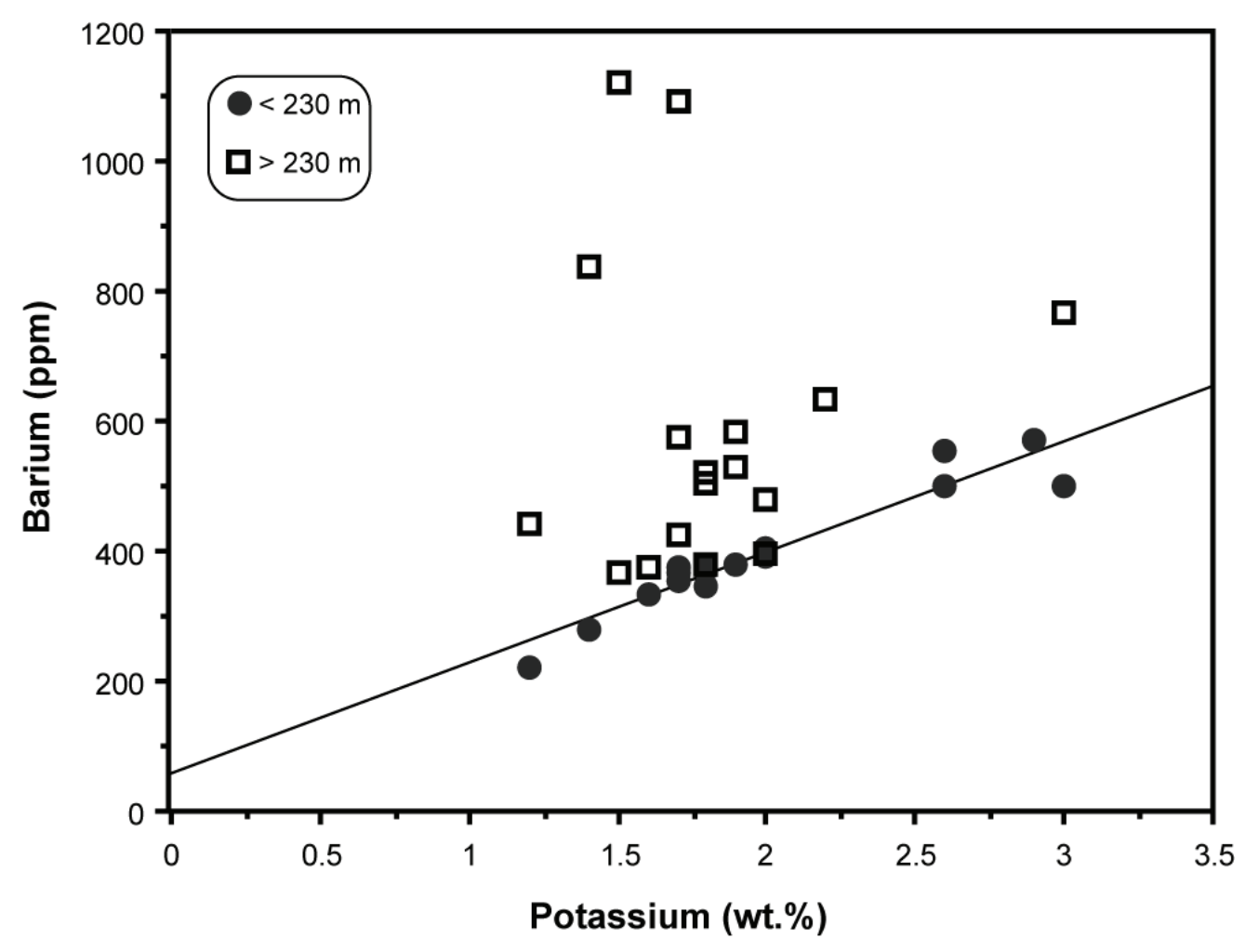

Figure 3. Plot of potassium vs. barium content of the Rajoir borehole sediment. Regression line was calculated using samples from depths less than $230 \mathrm{~m}\left(\mathrm{r}^{2}=0.9\right)$, which are unaffected by barite in the drilling mud. Scatter above the line is attributed to barite contamination. 


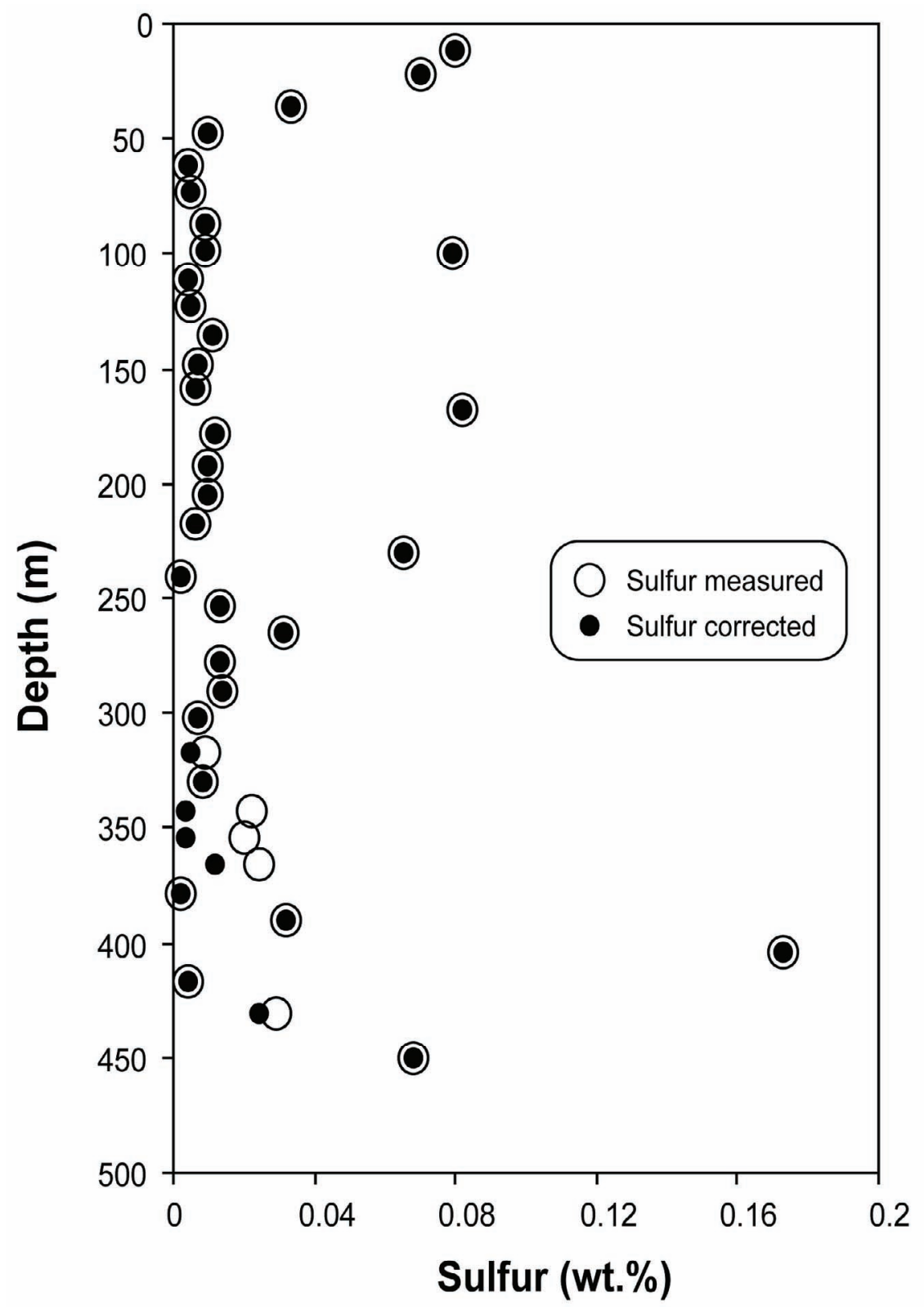

Figure 4. Depth profile comparing bulk sulfur concentration of the sediment from the Rajoir borehole with concentrations corrected for barite contamination. Only five of the 37 samples required significant correction. (wt.\%, weight percent). 
Table 1. Median, minimum and maximum concentrations of chemical constituents of sediment recovered from the SH-2 borehole in Rajoir, Bangladesh.

[ wt.\%, weight percent; ppm, parts per million; ICP-AES, Inductively Coupled Plasma Atomic Emission Spectroscopy; EDXRF, Energy Dispersive X-ray Fluorescence Spectrometry; HGAAS, Hydride Generation Atomic Absorption Spectrophotometry; *, sulfur concentrations are values corrected for barite contamination; detection ratio is the number of analyses above the detection limit/total number of analyses; nr, not reported]

\begin{tabular}{|c|c|c|c|c|c|}
\hline $\begin{array}{l}\text { Element } \\
\text { (units) }\end{array}$ & $\begin{array}{c}\text { Analytical } \\
\text { Method }\end{array}$ & Median & Minimum & Maximum & $\begin{array}{c}\text { Detection } \\
\text { Ratio }\end{array}$ \\
\hline $\mathrm{Al}$ (wt.\%) & ICP-AES & 4.9 & 3.2 & 11 & $37 / 37$ \\
\hline $\mathrm{Ca}($ wt. $\%)$ & ICP-AES & 0.83 & 0.4 & 1.5 & $37 / 37$ \\
\hline $\mathrm{Fe}($ wt.\%) & ICP-AES & 2.1 & 0.79 & 6.5 & $37 / 37$ \\
\hline K (wt.\%) & ICP-AES & 1.8 & 1.2 & 3.0 & $37 / 37$ \\
\hline $\mathrm{Mg}$ (wt.\%) & ICP-AES & 0.47 & 0.19 & 1.6 & $37 / 37$ \\
\hline $\mathrm{Na}$ (wt.\%) & ICP-AES & 1.1 & 0.22 & 1.4 & $37 / 37$ \\
\hline P (wt.\%) & ICP-AES & 0.025 & 0.009 & 0.061 & $37 / 37$ \\
\hline Ti (wt.\%) & ICP-AES & 0.24 & 0.098 & 0.48 & $37 / 37$ \\
\hline C-total (wt.\%) & Combustion & 0.11 & $<0.04$ & 1.1 & $34 / 37$ \\
\hline $\begin{array}{r}\text { C-carbonate } \\
\text { (wt.\%) }\end{array}$ & Chittick & 0.05 & 0.01 & 0.42 & $37 / 37$ \\
\hline S (wt.\%)* & Combustion & 0.01 & $<0.005$ & 0.17 & $36 / 37$ \\
\hline $\mathrm{Ag}(\mathrm{ppm})$ & ICP-AES & $<2$ & $<2$ & $<2$ & $0 / 37$ \\
\hline $\mathrm{Ag}(\mathrm{ppm})$ & EDXRF & $<1$ & $<1$ & $<1$ & $0 / 37$ \\
\hline As (ppm) & ICP-AES & $<10$ & $<10$ & 25 & $2 / 37$ \\
\hline As (ppm) & EDXRF & $<2$ & $<2$ & 21 & $10 / 37$ \\
\hline As (ppm) & HGAAS & 1.2 & 0.6 & 21 & $37 / 37$ \\
\hline $\mathrm{Au}(\mathrm{ppm})$ & ICP-AES & $<8$ & $<8$ & $<8$ & $0 / 37$ \\
\hline $\mathrm{Ba}(\mathrm{ppm})$ & ICP-AES & 400 & 220 & 1100 & $37 / 37$ \\
\hline $\mathrm{Ba}(\mathrm{ppm})$ & EDXRF & 440 & 250 & 1200 & $37 / 37$ \\
\hline $\mathrm{Be}(\mathrm{ppm})$ & ICP-AES & 2.1 & 1.3 & 4.2 & $37 / 37$ \\
\hline $\mathrm{Bi}(\mathrm{ppm})$ & ICP-AES & $<10$ & $<10$ & $<10$ & $37 / 37$ \\
\hline $\mathrm{Bi}(\mathrm{ppm})$ & EDXRF & $<5$ & $<5$ & $<5$ & $0 / 37$ \\
\hline $\mathrm{Br}(\mathrm{ppm})$ & EDXRF & $<1$ & $<1$ & 6 & $33 / 37$ \\
\hline $\mathrm{Cd}(\mathrm{ppm})$ & ICP-AES & $<2$ & $<2$ & $<2$ & $37 / 37$ \\
\hline $\mathrm{Cd}(\mathrm{ppm})$ & EDXRF & $<1$ & $<1$ & $<1$ & $0 / 37$ \\
\hline $\mathrm{Ce}(\mathrm{ppm})$ & ICP-AES & 67 & 29 & 110 & $37 / 37$ \\
\hline $\mathrm{Ce}(\mathrm{ppm})$ & EDXRF & 71 & 29 & 130 & $37 / 37$ \\
\hline Co (ppm) & ICP-AES & 7.9 & 2.4 & 48 & $37 / 37$ \\
\hline $\mathrm{Cr}(\mathrm{ppm})$ & ICP-AES & 36 & 12 & 110 & $37 / 37$ \\
\hline $\mathrm{Cr}(\mathrm{ppm})$ & EDXRF & 36 & 17 & 120 & $37 / 37$ \\
\hline Cs (ppm) & EDXRF & 8 & $<5$ & 18 & $32 / 37$ \\
\hline $\mathrm{Cu}(\mathrm{ppm})$ & ICP-AES & 6.6 & 2.1 & 76 & $37 / 37$ \\
\hline $\mathrm{Cu}(\mathrm{ppm})$ & EDXRF & $\mathrm{nr}$ & $\mathrm{nr}$ & $\mathrm{nr}$ & $\mathrm{nr}$ \\
\hline $\mathrm{Eu}(\mathrm{ppm})$ & ICP-AES & $<2$ & $<2$ & 2 & $1 / 37$ \\
\hline $\mathrm{Ga}(\mathrm{ppm})$ & ICP-AES & 9.6 & $<4$ & 30 & $33 / 37$ \\
\hline Ga (ppm) & EDXRF & 11 & 6 & 24 & $37 / 37$ \\
\hline $\mathrm{Ge}(\mathrm{ppm})$ & EDXRF & $<2$ & $<2$ & 4 & $1 / 37$ \\
\hline Ho (ppm) & ICP-AES & $<4$ & $<4$ & $<4$ & $0 / 37$ \\
\hline $\mathrm{La}(\mathrm{ppm})$ & ICP-AES & 33 & 14 & 58 & $37 / 37$ \\
\hline $\mathrm{La}(\mathrm{ppm})$ & EDXRF & 39 & 15 & 66 & $37 / 37$ \\
\hline
\end{tabular}


Table 1. Median, minimum and maximum of chemical constituents-Continued.

\begin{tabular}{|c|c|c|c|c|c|}
\hline $\begin{array}{c}\text { Element } \\
\text { (units) }\end{array}$ & $\begin{array}{c}\text { Analytical } \\
\text { Method }\end{array}$ & Median & Minimum & Maximum & $\begin{array}{c}\text { Detection } \\
\text { Ratio }\end{array}$ \\
\hline $\mathrm{Li}(\mathrm{ppm})$ & ICP-AES & 16 & 9.6 & 67 & $37 / 37$ \\
\hline $\mathrm{Mn}(\mathrm{ppm})$ & ICP-AES & 470 & 110 & 2800 & $37 / 37$ \\
\hline Mo (ppm) & ICP-AES & $<2$ & $<2$ & 3.4 & $3 / 37$ \\
\hline Mo (ppm) & EDXRF & $<2$ & $<2$ & 2 & $2 / 37$ \\
\hline $\mathrm{Nb}(\mathrm{ppm})$ & ICP-AES & 10 & $<4$ & 19 & $32 / 37$ \\
\hline $\mathrm{Nb}(\mathrm{ppm})$ & EDXRF & 9 & 5 & 19 & $37 / 37$ \\
\hline $\mathrm{Nd}(\mathrm{ppm})$ & ICP-AES & 30 & 12 & 44 & $37 / 37$ \\
\hline $\mathrm{Nd}(\mathrm{ppm})$ & EDXRF & 32 & $<10$ & 48 & $36 / 37$ \\
\hline $\mathrm{Ni}(\mathrm{ppm})$ & ICP-AES & 17 & 8.5 & 60 & $37 / 37$ \\
\hline $\mathrm{Ni}(\mathrm{ppm})$ & EDXRF & $\mathrm{nr}$ & $\mathrm{nr}$ & $\mathrm{nr}$ & $\mathrm{nr}$ \\
\hline $\mathrm{Pb}(\mathrm{ppm})$ & ICP-AES & 19 & 9.4 & 39 & $37 / 37$ \\
\hline $\mathrm{Pb}(\mathrm{ppm})$ & EDXRF & 18 & 13 & 37 & $37 / 37$ \\
\hline $\mathrm{Rb}(\mathrm{ppm})$ & EDXRF & 100 & 65 & 210 & $37 / 37$ \\
\hline $\mathrm{Sb}(\mathrm{ppm})$ & EDXRF & $<2$ & $<2$ & $<2$ & $0 / 37$ \\
\hline $\mathrm{Sc}(\mathrm{ppm})$ & ICP-AES & 7.6 & 3.2 & 18 & $37 / 37$ \\
\hline $\mathrm{Se}(\mathrm{ppm})$ & EDXRF & $<1$ & $<1$ & $<1$ & $0 / 37$ \\
\hline Sn (ppm) & ICP-AES & $<5$ & $<5$ & 30 & $6 / 37$ \\
\hline Sn (ppm) & EDXRF & 3 & $<2$ & 6 & $32 / 37$ \\
\hline $\mathrm{Sr}(\mathrm{ppm})$ & ICP-AES & 130 & 51 & 160 & $37 / 37$ \\
\hline $\mathrm{Sr}(\mathrm{ppm})$ & EDXRF & 140 & 54 & 170 & $37 / 37$ \\
\hline $\mathrm{Ta}(\mathrm{ppm})$ & ICP-AES & $<20$ & $<20$ & $<20$ & $37 / 37$ \\
\hline Th (ppm) & ICP-AES & $\mathrm{nr}$ & $\mathrm{nr}$ & $\mathrm{nr}$ & $\mathrm{nr}$ \\
\hline Th (ppm) & EDXRF & 11 & 5 & 24 & $37 / 37$ \\
\hline $\mathrm{U}(\mathrm{ppm})$ & ICP-AES & $<100$ & $<100$ & $<100$ & $0 / 37$ \\
\hline $\mathrm{U}(\mathrm{ppm})$ & EDXRF & $<4$ & $<4$ & 7 & $12 / 37$ \\
\hline $\mathrm{V}(\mathrm{ppm})$ & ICP-AES & 50 & 22 & 140 & $37 / 37$ \\
\hline $\mathrm{V}(\mathrm{ppm})$ & EDXRF & 51 & 24 & 140 & $37 / 37$ \\
\hline $\mathrm{W}(\mathrm{ppm})$ & EDXRF & $<5$ & $<5$ & 160 & $1 / 37$ \\
\hline $\mathrm{Y}(\mathrm{ppm})$ & ICP-AES & 16 & 7.6 & 29 & $37 / 37$ \\
\hline $\mathrm{Y}(\mathrm{ppm})$ & EDXRF & 22 & 12 & 37 & $37 / 37$ \\
\hline $\mathrm{Yb}(\mathrm{ppm})$ & ICP-AES & 1.8 & $<1$ & 3.6 & $34 / 37$ \\
\hline $\mathrm{Zn}(\mathrm{ppm})$ & ICP-AES & 39 & 24 & 120 & $37 / 37$ \\
\hline $\mathrm{Zn}(\mathrm{ppm})$ & EDXRF & 46 & 30 & 110 & $37 / 37$ \\
\hline $\mathrm{Zr}(\mathrm{ppm})$ & EDXRF & 130 & 98 & 290 & $37 / 37$ \\
\hline
\end{tabular}

\section{Chemical Extractions}

Analyses of the $0.5 \mathrm{~N} \mathrm{HCl}$ extraction solutions verified that the sediment is chemically reduced with respect to iron. $\mathrm{Fe}^{2+} / \mathrm{Fe}_{\text {total }}$ values are typically greater than 0.9 (Appendix 10). As much as 1 wt.\% iron was dissolved from the Rajoir sediment, which is tentatively attributed to dissolution of siderite. Substantial amounts of aluminum, calcium, magnesium, manganese, potassium, sodium, and silicon were also dissolved by $0.5 \mathrm{~N} \mathrm{HCl}$ (Appendix 11). These elements are attributed to dissolution of detrital silicates and siderite. Reaction of the acid with portions of feldspars, micas, and other detritus weathered during transport and shallow burial likely accounts for $\mathrm{Al}, \mathrm{Si}, \mathrm{K}, \mathrm{Na}$, and some of the $\mathrm{Ca}, \mathrm{Mg}$, and $\mathrm{Mn}$. Dissolution of siderite likely released $\mathrm{Ca}, \mathrm{Mg}$, and $\mathrm{Mn}$, as well as iron, based on preliminary analyses of siderite grains using a scanning electron microscope equipped with energy dispersive spectroscopy. 
Wilkin and Ford (2002) noted loss of dissolved arsenic in sulfidic sediment treated with $\mathrm{HCl}$ solutions that were intended to evaluate the abundance of labile arsenic. They attributed the arsenic loss to precipitation of amorphous orpiment $\left(\mathrm{As}_{2} \mathrm{~S}_{3}\right)$ by reaction of dissolved arsenic and $\mathrm{H}_{2} \mathrm{~S}$ evolved by reaction of the AVS with $\mathrm{HCl}$. Therefore, the arsenic concentrations of the $0.5 \mathrm{~N} \mathrm{HCl}$ extract solutions in this study should be viewed with caution. The potential of orpiment precipitation in the $0.5 \mathrm{~N} \mathrm{HCl}$ extraction was evaluated using Geochemist's Workbench with the LLNL V8 R6 combined database, which was modified with the thermodynamic data of Nordstrom and Archer (2003) and Pokrovski and others (2002). Results of AVS extraction (Appendix 12) and the abundance of arsenic and iron in the $0.5 \mathrm{~N} \mathrm{HCl}$ solutions (Appendix 11) were used to evaluate the degree of saturation of amorphous orpiment. The amount of AVS extracted by the $0.5 \mathrm{~N} \mathrm{HCl}$ is likely to be smaller than the AVS extracted by hot $6 \mathrm{~N} \mathrm{HCl}$, so the calculations are considered to indicate the maximum saturation values. One of the 8 samples analyzed for sulfur speciation was oversaturated with respect to amorphous orpiment. Samples selected for sulfur speciation generally contain greater contents of sulfur than most of the sediment samples; therefore, the remaining samples are unlikely to produce $\mathrm{HCl}$ extract solutions saturated with amorphous orpiment. This evaluation does not eliminate the concern for orpiment precipitation in the Rajoir sediment, but the problem is likely to be less significant than in the sediment evaluated by Wilkin and Ford (2002).

Sulfur speciation extractions detected AVS, acid-soluble sulfate, and reducible sulfur (DI) in the borehole sediment (Appendix 12). Concentrations of AVS ranged from 10 to $5250 \mathrm{ppm}$, acidsoluble sulfate measured 30 to $130 \mathrm{ppm}$, and DI was typically the most abundant form of sulfur, 30 to $9580 \mathrm{ppm}$. Reducible sulfide (DI) is attributed to pyrite. For several samples, the total amount of sulfur extracted is substantially different than the total sulfur concentrations measured for the bulk, air-dried sediment. The speciation scheme was evaluated with synthetic standards and determined to be reliable; therefore, the contrasting values are attributed to sample heterogeneity.

\section{References Cited}

Brammer, Hugh, 1996, The geography of the soils of Bangladesh: Dhaka, Bangladesh, The University Press Limited, 287 p.

Breit, G.N., Yount, J.C., Uddin, Md. N., Muneem, Ad. A., Lowers, H.A., Berry, C.J. and Whitney, J.W., 2006, Compositional data for Bengal delta sediment collected from boreholes at Srirampur, Kachua, Bangladesh: U.S. Geological Survey Open-File Report 2006-1222, 51 p. (http://pubs.er.usgs.gov/usgspubs/ofr/ofr20061222)

Briggs, P.H., 2002, Determination of forty elements in geological and botanical samples by inductively coupled plasma atomic emission spectrometry, in Taggart, J.E., ed., Analytical methods for chemical analysis of geologic and other materials: U.S. Geological Survey OpenFile Report 02-223, p. G1-G18. (http://pubs.usgs.gov/of/2002/ofr-02-0223/G01fortyelementICPAESsolid_M.pdf)

Brown, Z.A., and Curry, K.J., 2002a, Total sulfur by combustion, in Taggart, J.E., ed., Analytical methods for chemical analysis of geologic and other materials: U.S. Geological Survey OpenFile Report 02-223, p. Q1-Q4. (http://pubs.usgs.gov/of/2002/ofr-02-0223/Q25TotS_M.pdf)

Brown, Z.A., and Curry, K.J., 2002b, Total carbon by combustion, in Taggart, J.E., ed., Analytical methods for chemical analysis of geologic and other materials: U.S. Geological Survey Open- 
File Report 02-223, p. R1-R4. (http://pubs.usgs.gov/of/2002/ofr-02-

0223/RIOTotalCarbon_M.pdf)

Clesceri, L.S., Freenber, A.E., and Eaton, A.D., eds., 1998, 3500-Iron B. Phenanthroline method, in Standard methods for the examination of water and wastewater, $20^{\text {th }}$ edition: Washington, D.C., American Public Health Association, p. 3-76 to 3-78.

Dreimanis, A. 1962, Quantitative gasometric determination of calcite and dolomite by using Chittick apparatus: Journal of Sedimentary Petrology, v. 32, p. 520-529.

Eberl, D.D., 2003, A user's guide to ROCKJOCK-A program for determining quantitative mineralogy from powder X-ray diffraction data: U.S. Geological Survey Open-File Report 2003$78,41 \mathrm{p}$.

Goodbred, S.L., and Kuehl, S.A., 2000, The significance of large sediment supply, active tectonism, and eustasy on margin sequence development: Late Quaternary stratigraphy and evolution of the Ganges-Brahmaputra delta: Sedimentary Geology, v. 133, p. 227-248.

Gorair, R., Chakraborty, K.A., and Pyne, R., 1984, Chronic arsenic poisoning from tubewell water: Journal of the Indian Medical Association, v. 82, p. 34-35.

Hageman, P.L., Brown, Z.A., and Welsch, Eric, 2002, Arsenic and selenium by flow injection or continuous flow generation atomic absorption spectrophotometry, in Taggart, J.E., ed., Analytical methods for chemical analysis of geologic and other materials: U.S. Geological Survey OpenFile Report 02-223, p. L1-L7. (http://pubs.usgs.gov/of/2002/ofr-02-0223/L06AS24Se_M.pdf)

Harvey, C.F., Swartz, C.H., Badruzzaman, A.B.M., Keon-Blute, Nicole, Yu, Winston, Ali, M.A., Jay, Jenny, Beckie, Roger, Niedan, Volker, Brabander, Daniel, Oates, P.M., Ashfaque, K.N., Islam, Shafiqul, Hemond, H.F., and Ahmed, M.F., 2002, Arsenic mobility and ground water extraction in Bangladesh: Science, v. 298, p. 1602-1606.

Horneman, Alex, van Geen, Alex, Kent, D.V., Mathe, P.E., Zheng, Yan, Dhar, R.K., O'Connell, S., Hoque, M.A., Aziz, Z., Shasudduha, M., Seddique, A.A., and Ahmed, K.M., 2004, Decoupling of As and Fe release to Bangladesh groundwater under reducing conditions; Part 1, Evidence from sediment profiles: Geochimica et Cosmochimica Acta, v. 68, p. 3459-3473.

Nickson, R.T., McArthur, J.M., Ravenscroft, Peter, Burgess, W.G., and Ahmed, K.M., 2000, Mechanism of arsenic release to groundwater - Bangladesh and West Bengal: Applied Geochemistry, v. 15, p. 403-413.

Nordstrom, D.K. and Archer, D.G., 2003, Arsenic thermodynamic data and environmental geochemistry, in Welch A.H., and Stollenwerk, K.G., eds., Arsenic in groundwater: Dordrecht, Netherlands, Kluwer Academic Publishers, p. 1-26.

Pokrovski, G.S., Kara, Sami, and Roux, Jacques, 2002. Stability and solubility of arsenopyrite, FeAsS, in crustal fluids: Geochimica et Cosmochimica Acta, v. 66, p. 2361-2378. 
Puchelt, H., 1978, Barium, in Wedepohl, K.H., ed., Handbook of geochemistry, vol. II/4, Chapter O: Berlin, Germany, Springer-Verlag.

Ravenscroft, Peter, Burgess, W.G., Ahmed, K.M., Burren, Melanie, and Perrin, Jerome, 2005, Arsenic in groundwater of the Bengal basin, Bangladesh — Distribution, field relations and hydrogeological setting: Hydrogeology Journal, v. 13, p. 727-751.

Rice, C.A., Tuttle, M.L., and Reynolds, R.L., 1993, The analysis of forms of sulfur in ancient sediments and sedimentary rocks - Comments and cautions: Chemical Geology, v. 107, p. 8395.

Saha, K.C., 1984, Melanokeratosis from arsenical contamination of tubewell water: Indian Journal of Dermatology, v. 29, p. 37-46.

Saha, K.C., 1995, Chronic arsenic dermatosis from tubewell water in West Bengal during 1983-87: Indian Journal of Dermatology, v. 40, p. 1-12.

Siems, D.F., 2002, The determination of 30 elements in geological materials by energy dispersive $\mathrm{X}$-ray fluorescence spectrometry, in Taggart, J.E. ed., Analytical methods for chemical analysis of geologic and other materials: U.S. Geological Survey Open-File Report 02-223, p. U1-U11. (http://pubs.usgs.gov/of/2002/ofr-02-0223/U27edsfinal_U.pdf)

Smedley, P.L., and Kinniburgh, D.G., 2002, A review of the source, behavior and distribution of arsenic in natural waters: Applied Geochemistry, v. 17, p. 517-568.

Taggart, J.E., 2002, Analytical methods for chemical analysis of geologic and other materials: U.S. Geological Survey Open-file Report 02-223. http://pubs.usgs.gov/of/2002/ofr-02-0223/OFR-020223.pdf

Tuttle, M.L., Goldhaber, M.B., and Williamson, D.L., 1986, An analytical scheme for determining forms of sulfur in oil shales and associated rocks: Talanta, v. 33, p. 953-961.

Wentworth, C.K., 1922, A scale of grade and class terms for clastic sediments: Journal of Geology, v. 30, p. 377-392.

Wilkin, R.T., and Ford, R.G., 2002, Use of hydrochloric acid for determining solid-phase arsenic partitioning in sulfidic sediments: Environmental Science and Technology, v. 36, p. 4921-4927.

World Bank, 2005, Arsenic Contamination in Asia: http://siteresources.worldbank.org/INTSAREGTOPWATRES/Resources/ARSENIC_BRIEF.pdf 
Appendix 1. Depth interval and description of air-dried sediment samples from the SH-2 borehole, Rajoir, Bangladesh.

\begin{tabular}{|c|c|c|}
\hline Sample & $\begin{array}{c}\text { Depth } \\
\text { (meters) }\end{array}$ & Description \\
\hline $\mathrm{SH}-2 / 1-\mathrm{AD}$ & $11.0-11.1$ & light greenish-gray (10Y 7/1), silty clay \\
\hline $\mathrm{SH}-2 / 2-\mathrm{AD}$ & 21.6-21.9 & greenish-gray (5GY 6/1), fine sand \\
\hline SH-2/3-AD & $35.5-35.7$ & greenish-gray (10GY 6/1), fine sandy silt \\
\hline SH-2/4-AD & $47.9-48.2$ & greenish gray ( $5 \mathrm{GY} 5 / 1)$, fine sand \\
\hline SH-2/5-AD & $60.5-60.8$ & light greenish-gray (5GY 7/1), fine sand \\
\hline SH-2/6-AD & $72.5-72.8$ & greenish-gray (10GY 6/1), fine sand \\
\hline SH-2/7-AD & $86.3-86.6$ & greenish-gray (5GY 5/1), fine sand \\
\hline $\mathrm{SH}-2 / 8-\mathrm{AD}$ & $98.5-98.9$ & greenish gray ( $5 \mathrm{GY} 5 / 1)$, clayey medium sand \\
\hline SH-2/9-AD & $98.9-99.1$ & light greenish gray (10GY 7/1), clay \\
\hline SH-2/10-AD & $110.6-110.9$ & dark greenish gray (10Y 4/1) pebbly medium sand \\
\hline SH-2/11-AD & $122.2-123.1$ & light greenish gray (5BG 8/1), medium sand \\
\hline $\mathrm{SH}-2 / 12-\mathrm{AD}$ & $135.2-135.9$ & greenish gray, $(5 \mathrm{GY} 5 / 1)$, fine sand \\
\hline $\mathrm{SH}-2 / 13-\mathrm{AD}$ & $147.8-148.7$ & light greenish gray (5GY 7/1), fine sand \\
\hline SH-2/14-AD & $158.5-159.4$ & greenish gray $(10 \mathrm{Y} 6 / 1)$, fine sand \\
\hline $\mathrm{SH}-2 / 15-\mathrm{AD}$ & $167.0-167.6$ & light greenish gray, (5GY 7/1), clayey fine sand \\
\hline SH-2/16-AD & $178.9-179.8$ & light gray, $(2.5 \mathrm{Y} 7 / 2)$, silty fine sand \\
\hline SH-2/17-AD & $192.3-193.2$ & light gray $(5 \mathrm{Y} 7 / 2)$, pebbly medium sand \\
\hline $\mathrm{SH}-2 / 18-\mathrm{AD}$ & $204.2-205.1$ & light greenish gray (5BG $7 / 1)$, fine sand \\
\hline SH-2/19-AD & 217.3-217.8 & light greenish gray (10Y $7 / 1)$, medium sand \\
\hline SH-2/20-AD & $229.5-230.4$ & light greenish gray (5GY 7/1), medium sand \\
\hline SH-2/21-AD & $240.8-241.7$ & greenish gray (10Y 6/1), pebbly medium sand \\
\hline $\mathrm{SH}-2 / 22-\mathrm{AD}$ & $253.0-253.9$ & greenish gray (10Y 6/1), pebbly medium sand \\
\hline $\mathrm{SH}-2 / 23-\mathrm{AD}$ & $265.2-266.1$ & light greenish gray ( $5 G Y 7 / 1)$ clayey fine sand \\
\hline SH-2/24-AD & $277.4-278.0$ & greenish gray (5BG 6/1), clayey medium sand \\
\hline $\mathrm{SH}-2 / 25-\mathrm{AD}$ & $289.6-290.3$ & light greenish gray (10BG $7 / 1)$ fine sand \\
\hline $\mathrm{SH}-2 / 26-\mathrm{AD}$ & $301.8-302.7$ & light greenish gray (5BG 7/1), medium sand \\
\hline SH-2/27-AD & $316.8-317.0$ & light bluish gray (5B 7/1), fine sandy clay \\
\hline $\mathrm{SH}-2 / 28-\mathrm{AD}$ & $329.8-330.1$ & light greenish gray (10GY $7 / 1)$, medium sand \\
\hline SH-2/29-AD & $342.6-343.2$ & very pale brown $(10 \mathrm{YR} 7 / 3)$, fine sand \\
\hline SH-2/30-AD & $353.6-354.5$ & light brownish gray (10YR 6/2), medium sand \\
\hline $\mathrm{SH}-2 / 31-\mathrm{AD}$ & $365.8-366.7$ & pale brown (10YR $6 / 3)$ medium sand \\
\hline SH-2/32-AD & $378.6-378.9$ & mottled light gray (10YR7/1) and brown-yellow (10YR 6/6) clay \\
\hline $\mathrm{SH}-2 / 33-\mathrm{AD}$ & $390.1-391.1$ & light greenish gray (10GY 7/1) fine sandy, silty clay \\
\hline $\mathrm{SH}-2 / 34-\mathrm{AD}$ & 403.3-404.2 & light greenish gray (10GY $7 / 1)$ fine sandy clay \\
\hline $\mathrm{SH}-2 / 35-\mathrm{AD}$ & $416.4-417.3$ & greenish gray $(5 \mathrm{GY} 6 / 1)$ fine sand \\
\hline SH-2/36-AD & $429.8-430.7$ & very pale brown $(10 \mathrm{YR} 7 / 3)$, fine sand \\
\hline SH-2/37-AD & $449.6-450.5$ & greenish gray (5GY 6/1) fine sandy clay \\
\hline
\end{tabular}


Appendix 2. Depth of sediment samples that were preserved in glass vials, flushed with argon, and frozen after collection from the SH-2 borehole, Rajoir, Bangladesh.

\begin{tabular}{cc}
\hline Sample & $\begin{array}{c}\text { Depth } \\
\text { (meters) }\end{array}$ \\
\hline SH-2/1-P & 11.6 \\
SH-2/2-P & 21.9 \\
SH-2/3-P & 35.7 \\
SH-2/4-P & 48.2 \\
SH-2/5-P & 60.8 \\
SH-2/6-P & 72.8 \\
SH-2/7-P & 86.6 \\
SH-2/8-P & 98.9 \\
SH-2/9-P & 99.1 \\
SH-2/10-P & 110.9 \\
SH-2/11-P & 123.1 \\
SH-2/12-P & 135.9 \\
SH-2/13-P & 148.7 \\
SH-2/14-P & 159.4 \\
SH-2/15-P & 167.6 \\
SH-2/16-P & 179.8 \\
SH-2/17-P & 193.2 \\
SH-2/18-P & 205.1 \\
SH-2/19-P & 217.8 \\
SH-2/20-P & 230.4 \\
SH-2/21-P & 241.7 \\
SH-2/22-P & 253.9 \\
SH-2/23-P & 266.1 \\
SH-2/24-P & 278.0 \\
SH-2/25-P & 290.3 \\
SH-2/26-P & 302.7 \\
SH-2/27-P & 317.0 \\
SH-2/28-P & 330.1 \\
SH-2/29-P & 343.2 \\
SH-2/30-P & 354.5 \\
SH-2/31-P & 366.7 \\
SH-2/32-P & 378.9 \\
SH-2/33-P & 391.1 \\
SH-2/34-P & 404.2 \\
SH-2/35-P & 417.3 \\
SH-2/36-P & 430.7 \\
SH-2/37-P & 450.5 \\
\hline
\end{tabular}


Appendix 3. Results of grain size analysis of air-dried sediment samples collected from the SH-2 borehole, Rajoir village, Bangladesh. Designations as sand, silt, and clay follow the size definitions of Wentworth (1922).

[Eric Fisher, Analyst; wt.\%, weight percent]

\begin{tabular}{|c|c|c|c|c|}
\hline Sample & $\begin{array}{c}\text { Sand } \\
\text { (wt.\%) }\end{array}$ & $\begin{array}{c}\text { Silt } \\
\text { (wt.\%) }\end{array}$ & $\begin{array}{c}\text { Clay } \\
\text { (wt. \%) }\end{array}$ & Description \\
\hline SH-2/1-AD & 6.5 & 80.0 & 13.6 & silt \\
\hline SH-2/2-AD & 69.8 & 27.7 & 2.4 & silty sand \\
\hline SH-2/3-AD & 27.6 & 62.1 & 10.3 & sandy silt \\
\hline SH-2/4-AD & 89.3 & 9.1 & 1.6 & sand \\
\hline SH-2/5-AD & 87.4 & 10.9 & 1.7 & sand \\
\hline SH-2/6-AD & 81.7 & 16.0 & 2.3 & sand \\
\hline SH-2/7-AD & 89.2 & 8.5 & 2.4 & sand \\
\hline SH-2/8-AD & 92.3 & 6.1 & 1.6 & sand \\
\hline SH-2/9-AD & 20.9 & 57.8 & 21.3 & sandy silt \\
\hline SH-2/10-AD & 73.1 & 23.7 & 3.2 & silty sand \\
\hline SH-2/11-AD & 86.9 & 11.1 & 1.9 & sand \\
\hline $\mathrm{SH}-2 / 12-\mathrm{AD}$ & 87.6 & 11.4 & 1.0 & sand \\
\hline SH-2/13-AD & 94.9 & 4.5 & 0.6 & sand \\
\hline SH-2/14-AD & 90.6 & 8.2 & 1.2 & sand \\
\hline SH-2/15-AD & 79.9 & 17.3 & 2.9 & sand \\
\hline SH-2/16-AD & 93.5 & 5.2 & 1.3 & sand \\
\hline SH-2/17-AD & 89.7 & 8.5 & 1.8 & sand \\
\hline SH-2/18-AD & 94.8 & 4.5 & 0.7 & sand \\
\hline SH-2/19-AD & 94.6 & 4.5 & 0.9 & sand \\
\hline SH-2/20-AD & 96.5 & 3.0 & 0.5 & sand \\
\hline SH-2/21-AD & 90.6 & 8.2 & 1.3 & sand \\
\hline $\mathrm{SH}-2 / 22-\mathrm{AD}$ & 95.0 & 4.5 & 0.5 & sand \\
\hline $\mathrm{SH}-2 / 23-\mathrm{AD}$ & 85.0 & 12.6 & 2.4 & sand \\
\hline SH-2/24-AD & 94.2 & 5.2 & 0.6 & sand \\
\hline $\mathrm{SH}-2 / 25-\mathrm{AD}$ & 91.1 & 8.0 & 0.9 & sand \\
\hline SH-2/26-AD & 98.2 & 1.4 & 0.4 & sand \\
\hline $\mathrm{SH}-2 / 27-\mathrm{AD}$ & 79.2 & 17.4 & 3.4 & sand \\
\hline $\mathrm{SH}-2 / 28-\mathrm{AD}$ & 96.7 & 2.8 & 0.5 & sand \\
\hline $\mathrm{SH}-2 / 29-\mathrm{AD}$ & 92.9 & 6.2 & 1.0 & sand \\
\hline $\mathrm{SH}-2 / 30-\mathrm{AD}$ & 94.2 & 4.9 & 1.0 & sand \\
\hline SH-2/31-AD & 90.9 & 7.2 & 1.9 & sand \\
\hline SH-2/32-AD & 1.6 & 45.4 & 53.0 & silty clay \\
\hline $\mathrm{SH}-2 / 33-\mathrm{AD}$ & 22.3 & 57.0 & 20.7 & sandy silt \\
\hline SH-2/34-AD & 17.1 & 66.3 & 16.6 & sandy silt \\
\hline SH-2/35-AD & 94.7 & 4.3 & 1.0 & sand \\
\hline SH-2/36-AD & 94.7 & 4.2 & 1.1 & sand \\
\hline SH-2/37-AD & 23.6 & 66.8 & 9.6 & sandy silt \\
\hline
\end{tabular}


Appendix 4. Major and minor minerals detected by X-ray diffraction analysis of air-dried sediment samples from the SH-2 borehole, Rajoir, Bangladesh.

[XX, major constituent; X, minor constituent; TI, tentative identification as minor phase; <, not detected; Plag., plagioclase; K-spar, potassium feldspar; Amph., amphibole]

\begin{tabular}{|c|c|c|c|c|c|c|c|}
\hline Sample & Quartz & Plag. & K-spar & Mica & Chlorite & Amph. & Siderite \\
\hline SH-2/1-AD & XX & $X$ & $X$ & $\mathrm{X}$ & TI & TI & $<$ \\
\hline SH-2/2-AD & XX & $\mathrm{X}$ & $\mathrm{X}$ & $\mathrm{X}$ & TI & $\mathrm{X}$ & $<$ \\
\hline $\mathrm{SH}-2 / 3-\mathrm{AD}$ & $\mathrm{XX}$ & $\mathrm{X}$ & $\mathrm{X}$ & $\mathrm{X}$ & TI & $\mathrm{X}$ & $<$ \\
\hline SH-2/4-AD & $\mathrm{XX}$ & $\mathrm{X}$ & $\mathrm{X}$ & $<$ & TI & $\mathrm{X}$ & $<$ \\
\hline $\mathrm{SH}-2 / 5-\mathrm{AD}$ & $\mathrm{XX}$ & $\mathrm{X}$ & $\mathrm{X}$ & $\mathrm{X}$ & TI & $\mathrm{X}$ & $<$ \\
\hline $\mathrm{SH}-2 / 6-\mathrm{AD}$ & $\mathrm{XX}$ & $\mathrm{X}$ & $\mathrm{X}$ & $\mathrm{X}$ & TI & $\mathrm{X}$ & $<$ \\
\hline SH-2/7-AD & XX & $\mathrm{X}$ & $\mathrm{X}$ & $X$ & TI & $\mathrm{X}$ & $<$ \\
\hline $\mathrm{SH}-2 / 8-\mathrm{AD}$ & XX & $\mathrm{X}$ & $\mathrm{X}$ & $\mathrm{X}$ & TI & TI & $<$ \\
\hline SH-2/9-AD & $\mathrm{XX}$ & $\mathrm{X}$ & TI & $X$ & TI & TI & $<$ \\
\hline SH-2/10-AD & $\mathrm{XX}$ & $\mathrm{X}$ & TI & $\mathrm{X}$ & $<$ & TI & TI \\
\hline SH-2/11-AD & XX & $\mathrm{X}$ & TI & $\mathrm{X}$ & TI & TI & $<$ \\
\hline SH-2/12-AD & $\mathrm{XX}$ & $\mathrm{X}$ & $X$ & $X$ & TI & $<$ & TI \\
\hline SH-2/13-AD & $\mathrm{XX}$ & $\mathrm{X}$ & $\mathrm{X}$ & $X$ & TI & TI & $<$ \\
\hline SH-2/14-AD & $\mathrm{XX}$ & $\mathrm{X}$ & TI & $\mathrm{X}$ & $<$ & TI & $<$ \\
\hline $\mathrm{SH}-2 / 15-\mathrm{AD}$ & $\mathrm{XX}$ & $\mathrm{X}$ & $X$ & $\mathrm{X}$ & TI & $<$ & $<$ \\
\hline SH-2/16-AD & $\mathrm{XX}$ & $\mathrm{X}$ & $\mathrm{X}$ & $\mathrm{TI}$ & $<$ & $<$ & $<$ \\
\hline SH-2/17-AD & $\mathrm{XX}$ & $\mathrm{X}$ & $X$ & $\mathrm{X}$ & TI & TI & $<$ \\
\hline SH-2/18-AD & XX & $\mathrm{X}$ & $\mathrm{X}$ & $\mathrm{X}$ & TI & $X$ & $<$ \\
\hline SH-2/19-AD & XX & $\mathrm{X}$ & $\mathrm{X}$ & $\mathrm{X}$ & TI & TI & TI \\
\hline $\mathrm{SH}-2 / 20-\mathrm{AD}$ & $\mathrm{XX}$ & $\mathrm{X}$ & $X$ & $\mathrm{X}$ & $\mathrm{X}$ & $X$ & $<$ \\
\hline SH-2/21-AD & $\mathrm{XX}$ & $\mathrm{X}$ & $X$ & $\mathrm{X}$ & TI & TI & $<$ \\
\hline SH-2/22-AD & $\mathrm{XX}$ & $\mathrm{X}$ & $\mathrm{X}$ & $\mathrm{X}$ & TI & $\mathrm{X}$ & TI \\
\hline $\mathrm{SH}-2 / 23-\mathrm{AD}$ & $\mathrm{XX}$ & $\mathrm{X}$ & $\mathrm{X}$ & $\mathrm{X}$ & TI & TI & $X$ \\
\hline SH-2/24-AD & $\mathrm{XX}$ & $\mathrm{X}$ & $\mathrm{X}$ & $X$ & TI & TI & $<$ \\
\hline SH-2/25-AD & XX & $X$ & $\mathrm{X}$ & $\mathrm{X}$ & TI & TI & TI \\
\hline SH-2/26-AD & $\mathrm{XX}$ & $\mathrm{X}$ & $X$ & $X$ & TI & $X$ & $X$ \\
\hline SH-2/27-AD & $\mathrm{XX}$ & $\mathrm{X}$ & $X$ & $\mathrm{X}$ & $<$ & TI & $<$ \\
\hline SH-2/28-AD & $\mathrm{XX}$ & $\mathrm{X}$ & $\mathrm{X}$ & $X$ & TI & $\mathrm{TI}$ & $\mathrm{X}$ \\
\hline SH-2/29-AD & $\mathrm{XX}$ & $\mathrm{X}$ & $\mathrm{X}$ & $X$ & TI & $\mathrm{X}$ & $<$ \\
\hline SH-2/30-AD & XX & $X$ & $X$ & $\mathrm{X}$ & $<$ & TI & $<$ \\
\hline SH-2/31-AD & $\mathrm{XX}$ & $\mathrm{X}$ & $X$ & $\mathrm{X}$ & TI & $X$ & $<$ \\
\hline SH-2/32-AD & $\mathrm{XX}$ & $X$ & $\mathrm{X}$ & $X$ & $X$ & TI & $<$ \\
\hline SH-2/33-AD & $\mathrm{XX}$ & $\mathrm{X}$ & $X$ & $\mathrm{X}$ & $<$ & $<$ & $X$ \\
\hline SH-2/34-AD & $\mathrm{XX}$ & $X$ & $X$ & $\mathrm{X}$ & $<$ & TI & $<$ \\
\hline SH-2/35-AD & XX & $X$ & $\mathrm{X}$ & $\mathrm{X}$ & TI & $X$ & $<$ \\
\hline SH-2/36-AD & XX & $\mathrm{X}$ & $\mathrm{X}$ & $\mathrm{X}$ & TI & TI & $<$ \\
\hline SH-2/37-AD & $\mathrm{XX}$ & $\mathrm{X}$ & $\mathrm{X}$ & $\mathrm{X}$ & TI & $<$ & $<$ \\
\hline
\end{tabular}


Appendix 5. Results of quantitative mineralogical analysis by X-ray diffraction of air-dried sediment samples from the GSB borehole SH-2 borehole at Rajoir, Bangladesh. Abundances determined using the ROCKJOCK procedure of Eberl (2002).

[K-spar, potassium feldspars; Plag., plagioclase; Amph., amphibole; Mica, sum of muscovite, phlogopite and biotite; wt.\%, weight percent]

\begin{tabular}{|c|c|c|c|c|c|c|c|c|c|}
\hline Sample & $\begin{array}{l}\text { Quartz } \\
\text { (wt.\%) }\end{array}$ & $\begin{array}{l}\text { K-spar } \\
\text { (wt.\%) }\end{array}$ & $\begin{array}{l}\text { Plag. } \\
\text { (wt. \%) }\end{array}$ & $\begin{array}{l}\text { Amph. } \\
\text { (wt.\%) }\end{array}$ & $\begin{array}{c}\text { Mica } \\
\text { (wt.\%) }\end{array}$ & $\begin{array}{c}\text { Chlorite } \\
\text { (wt. \%) }\end{array}$ & $\begin{array}{c}\text { Smectite } \\
\text { (wt.\%) }\end{array}$ & $\begin{array}{c}\text { Kaolinite } \\
\text { (wt.\%) }\end{array}$ & $\begin{array}{c}\text { Siderite } \\
\text { (wt.\%) }\end{array}$ \\
\hline SH-2/1-AD & 34 & 8 & 13 & 2 & 30 & 9 & $<1$ & 2 & $<1$ \\
\hline $\mathrm{SH}-2 / 2-\mathrm{AD}$ & 45 & 12 & 17 & 4 & 13 & 7 & 2 & $<1$ & $<1$ \\
\hline $\mathrm{SH}-2 / 12-\mathrm{AD}$ & 34 & 14 & 13 & 1 & 22 & 5 & 7 & 2 & 1 \\
\hline SH-2/15-AD & 54 & 14 & 9 & 1 & 9 & 3 & 7 & 1 & 2 \\
\hline $\mathrm{SH}-2 / 18-\mathrm{AD}$ & 50 & 15 & 16 & 3 & 7 & 5 & 3 & 1 & $<1$ \\
\hline SH-2/28-AD & 57 & 13 & 13 & 2 & 6 & 5 & 4 & $<1$ & 1 \\
\hline $\mathrm{SH}-2 / 32-\mathrm{AD}$ & 22 & 8 & $<1$ & $<1$ & 27 & 5 & 20 & 8 & $<1$ \\
\hline SH-2/36-AD & 59 & 14 & 14 & 2 & 6 & 2 & 3 & $<1$ & $<1$ \\
\hline
\end{tabular}


Appendix 6. Results of carbon and sulfur analyses of air-dried sediment samples from the SH-2 borehole, Rajoir, Bangladesh. Sulfur and total carbon determined by Combustion (Brown and Curry, 2002a; 2002b). Carbonate carbon determined using the Chittick method (Dreimanis, 1962). Sulfur was corrected (Sulfur (corr)) for barite contamination as described in the text.

[wt.\%, weight percent]

\begin{tabular}{|c|c|c|c|c|}
\hline Sample & $\begin{array}{l}\text { Sulfur } \\
\text { (wt.\%) }\end{array}$ & $\begin{array}{l}\text { Sulfur (corr) } \\
\text { (wt.\%) }\end{array}$ & $\begin{array}{c}\text { Total Carbon } \\
\text { (wt.\%) }\end{array}$ & $\begin{array}{c}\text { Carbonate Carbon } \\
\text { (wt.\%) }\end{array}$ \\
\hline SH-1/1-AD & 0.080 & 0.080 & 0.33 & 0.05 \\
\hline SH-1/2-AD & 0.070 & 0.070 & 0.29 & 0.30 \\
\hline SH-1/3-AD & 0.033 & 0.033 & 0.60 & 0.22 \\
\hline SH-1/4-AD & 0.010 & 0.010 & 0.11 & 0.07 \\
\hline SH-1/5-AD & 0.004 & 0.004 & 0.09 & 0.05 \\
\hline SH-1/6-AD & 0.005 & 0.005 & 0.11 & 0.04 \\
\hline SH-1/7-AD & 0.009 & 0.009 & 0.05 & 0.04 \\
\hline SH-1/8-AD & 0.009 & 0.009 & 0.15 & 0.15 \\
\hline SH-1/9-AD & 0.079 & 0.079 & 1.1 & 0.20 \\
\hline SH-1/10-AD & 0.004 & 0.004 & 0.41 & 0.14 \\
\hline SH-1/11-AD & 0.005 & 0.005 & 0.09 & 0.04 \\
\hline SH-1/12-AD & 0.011 & 0.011 & 0.21 & 0.09 \\
\hline SH-1/13-AD & 0.007 & 0.007 & 0.10 & 0.07 \\
\hline SH-1/14-AD & 0.006 & 0.006 & 0.11 & 0.08 \\
\hline SH-1/15-AD & 0.082 & 0.082 & 0.46 & 0.12 \\
\hline SH-1/16-AD & 0.012 & 0.012 & 0.04 & 0.04 \\
\hline SH-1/17-AD & 0.010 & 0.010 & 0.05 & 0.02 \\
\hline SH-1/18-AD & 0.010 & 0.010 & 0.07 & 0.07 \\
\hline SH-1/19-AD & 0.006 & 0.006 & 0.20 & 0.07 \\
\hline SH- $1 / 20-A D$ & 0.065 & 0.065 & 0.06 & 0.03 \\
\hline SH-1/21-AD & 0.002 & 0.002 & $<0.04$ & 0.03 \\
\hline SH-1/22-AD & 0.013 & 0.013 & 0.10 & 0.04 \\
\hline SH-1/23-AD & 0.031 & 0.031 & 0.30 & 0.06 \\
\hline SH-1/24-AD & 0.013 & 0.013 & 0.11 & 0.04 \\
\hline SH-1/25-AD & 0.014 & 0.014 & 0.13 & 0.07 \\
\hline SH-1/26-AD & 0.007 & 0.007 & 0.41 & 0.03 \\
\hline SH-1/27-AD & 0.009 & 0.005 & $<0.04$ & 0.04 \\
\hline SH-1/28-AD & 0.008 & 0.008 & 0.20 & 0.11 \\
\hline SH-1/29-AD & 0.022 & 0.004 & 0.06 & 0.05 \\
\hline SH-1/30-AD & 0.020 & 0.003 & $<0.04$ & 0.04 \\
\hline SH-1/31-AD & 0.024 & 0.012 & 0.06 & 0.04 \\
\hline SH-1/32-AD & $<0.002$ & $<0.002$ & 0.10 & 0.05 \\
\hline SH-1/33-AD & 0.032 & 0.032 & 0.59 & 0.42 \\
\hline SH-1/34-AD & 0.173 & 0.173 & 0.10 & 0.04 \\
\hline SH-1/35-AD & 0.004 & 0.004 & $<0.04$ & 0.04 \\
\hline SH-1/36-AD & 0.029 & 0.024 & 0.05 & 0.03 \\
\hline SH-1/37-AD & 0.068 & 0.068 & 0.22 & 0.09 \\
\hline
\end{tabular}


Appendix 7. Results of Inductively Coupled Plasma Atomic Emission Spectroscopy (ICP-AES) analyses of air-dried samples from the SH-2 borehole, Rajoir, Bangladesh.

[Paul Briggs, USGS, Analyst; wt.\% weight percent; ppm, parts per million; nr, not reported]

\begin{tabular}{|c|c|c|c|c|c|c|c|c|c|c|c|c|c|c|}
\hline Sample & $\begin{array}{c}\text { Al } \\
\text { wt. \% }\end{array}$ & $\begin{array}{c}\text { Ca } \\
\text { wt. \% }\end{array}$ & $\begin{array}{c}\text { Fe } \\
\text { wt. } \%\end{array}$ & $\begin{array}{c}\text { K } \\
\text { wt. \% }\end{array}$ & $\begin{array}{c}\text { Mg } \\
\text { wt. \% }\end{array}$ & $\begin{array}{c}\mathrm{Na} \\
\text { wt. } \%\end{array}$ & $\begin{array}{c}\mathbf{P} \\
\text { wt. \% }\end{array}$ & $\begin{array}{c}\mathrm{Ti} \\
\text { wt. \% }\end{array}$ & $\begin{array}{c}\mathrm{Ag} \\
\mathrm{ppm}\end{array}$ & $\begin{array}{c}\text { As } \\
\text { ppm }\end{array}$ & $\begin{array}{c}\text { Au } \\
\text { ppm }\end{array}$ & $\begin{array}{c}\text { Ba } \\
\text { ppm }\end{array}$ & $\begin{array}{c}\text { Be } \\
\text { ppm }\end{array}$ & $\begin{array}{c}\mathrm{Bi} \\
\mathrm{ppm}\end{array}$ \\
\hline SH-2/1-AD & 8.7 & 0.87 & 4.0 & 2.9 & 1.5 & 1.1 & 0.050 & 0.45 & $<2$ & $<10$ & $<8$ & 570 & 3.1 & $<10$ \\
\hline $\mathrm{SH}-2 / 2-\mathrm{AD}$ & 5.8 & 1.5 & 2.9 & 2.0 & 1.1 & 1.3 & 0.060 & 0.33 & $<2$ & $<10$ & $<8$ & 400 & 2.1 & $<10$ \\
\hline SH-2/3-AD & 8.0 & 1.3 & 4.2 & 2.6 & 1.6 & 1.2 & 0.061 & 0.44 & $<2$ & $<10$ & $<8$ & 500 & 2.9 & $<10$ \\
\hline SH-2/4-AD & 5.7 & 1.4 & 2.5 & 2.0 & 0.8 & 1.4 & 0.036 & 0.28 & $<2$ & $<10$ & $<8$ & 390 & 2.1 & $<10$ \\
\hline SH-2/5-AD & 5.5 & 1.4 & 2.3 & 1.8 & 0.69 & 1.4 & 0.038 & 0.28 & $<2$ & $<10$ & $<8$ & 370 & 2.2 & $<10$ \\
\hline SH-2/6-AD & 5.4 & 1.2 & 2.1 & 1.9 & 0.67 & 1.4 & 0.028 & 0.22 & $<2$ & $<10$ & $<8$ & 380 & 2.0 & $<10$ \\
\hline SH-2/7-AD & 4.6 & 1.0 & 1.6 & 1.6 & 0.47 & 1.3 & 0.023 & 0.14 & $<2$ & $<10$ & $<8$ & 330 & 1.8 & $<10$ \\
\hline SH-2/8-AD & 3.6 & 0.51 & 1.9 & 1.4 & 0.4 & 0.77 & 0.021 & 0.12 & $<2$ & $<10$ & $<8$ & 280 & 1.3 & $<10$ \\
\hline SH-2/9-AD & 9.0 & 1.0 & 4.7 & 2.6 & 1.5 & 1.1 & 0.053 & 0.41 & $<2$ & 15 & $<8$ & 550 & 3.2 & $<10$ \\
\hline SH-2/10-AD & 3.2 & 0.72 & 2.7 & 1.2 & 0.42 & 0.74 & 0.024 & 0.10 & $<2$ & $<10$ & $<8$ & 220 & 1.7 & $<10$ \\
\hline $\mathrm{SH}-2 / 11-\mathrm{AD}$ & 4.9 & 1.0 & 1.5 & 1.8 & 0.44 & 1.3 & 0.023 & 0.16 & $<2$ & $<10$ & $<8$ & 350 & 2.0 & $<10$ \\
\hline $\mathrm{SH}-2 / 12-\mathrm{AD}$ & 7.5 & 0.59 & 4.2 & 3.0 & 1.1 & 1.2 & 0.019 & 0.41 & $<2$ & $<10$ & $<8$ & 500 & 2.5 & $<10$ \\
\hline $\mathrm{SH}-2 / 13-\mathrm{AD}$ & 4.8 & 0.89 & 1.8 & 1.7 & 0.42 & 1.1 & 0.027 & 0.25 & $<2$ & $<10$ & $<8$ & 350 & 1.8 & $<10$ \\
\hline SH-2/14-AD & 5.4 & 0.87 & 2.1 & 2.0 & 0.52 & 1.2 & 0.028 & 0.25 & $<2$ & $<10$ & $<8$ & 390 & 1.9 & $<10$ \\
\hline $\mathrm{SH}-2 / 15-\mathrm{AD}$ & 4.9 & 0.55 & 3.1 & 1.7 & 0.46 & 0.75 & 0.023 & 0.28 & $<2$ & $<10$ & $<8$ & 370 & 2.0 & $<10$ \\
\hline SH-2/16-AD & 3.9 & 0.49 & 0.79 & 1.8 & 0.19 & 0.87 & 0.009 & 0.11 & $<2$ & $<10$ & $<8$ & 380 & 1.5 & $<10$ \\
\hline SH-2/17-AD & 5.4 & 0.86 & 1.5 & 2.0 & 0.44 & 1.3 & 0.024 & 0.21 & $<2$ & $<10$ & $<8$ & 390 & 2.2 & $<10$ \\
\hline SH-2/18-AD & 5.2 & 1.0 & 1.9 & 1.7 & 0.49 & 1.2 & 0.028 & 0.25 & $<2$ & $<10$ & $<8$ & 380 & 1.9 & $<10$ \\
\hline SH-2/19-AD & 4.9 & 0.78 & 2.0 & 1.8 & 0.48 & 1.1 & 0.023 & 0.21 & $<2$ & $<10$ & $<8$ & 380 & 2.2 & $<10$ \\
\hline $\mathrm{SH}-2 / 20-\mathrm{AD}$ & 4.9 & 0.79 & 1.3 & 1.8 & 0.35 & 1.2 & 0.019 & 0.16 & $<2$ & $<10$ & $<8$ & 380 & 1.9 & $<10$ \\
\hline $\mathrm{SH}-2 / 21-\mathrm{AD}$ & 4.5 & 0.77 & 1.5 & 1.7 & 0.36 & 1.1 & 0.023 & 0.18 & $<2$ & $<10$ & $<8$ & 430 & 1.9 & $<10$ \\
\hline SH-2/22-AD & 4.9 & 0.68 & 1.5 & 1.8 & 0.37 & 1.1 & 0.020 & 0.18 & $<2$ & $<10$ & $<8$ & 520 & 1.9 & $<10$ \\
\hline SH-2/23-AD & 5.2 & 0.61 & 2.3 & 2.0 & 0.45 & 1.1 & 0.021 & 0.18 & $<2$ & $<10$ & $<8$ & 480 & 2.2 & $<10$ \\
\hline SH-2/24-AD & 5.4 & 0.81 & 1.9 & 1.9 & 0.6 & 1.1 & 0.025 & 0.25 & $<2$ & $<10$ & $<8$ & 530 & 2.1 & $<10$ \\
\hline $\mathrm{SH}-2 / 25-\mathrm{AD}$ & 5.4 & 0.86 & 2.1 & 1.8 & 0.54 & 1.2 & 0.034 & 0.25 & $<2$ & $<10$ & $<8$ & 380 & 2.3 & $<10$ \\
\hline $\mathrm{SH}-2 / 26-\mathrm{AD}$ & 4.6 & 0.53 & 2.6 & 2.0 & 0.36 & 1.1 & 0.022 & 0.14 & $<2$ & $<10$ & $<8$ & 400 & 2.3 & $<10$ \\
\hline $\mathrm{SH}-2 / 27-\mathrm{AD}$ & 4.9 & 0.67 & 1.4 & 1.9 & 0.38 & 1.2 & 0.021 & 0.17 & $<2$ & $<10$ & $<8$ & 590 & 2.1 & $<10$ \\
\hline
\end{tabular}


Appendix 7. Results of ICP-AES analyses - Continued.

\begin{tabular}{|c|c|c|c|c|c|c|c|c|c|c|c|c|c|c|}
\hline Sample & $\begin{array}{c}\text { Al } \\
\text { wt. } \%\end{array}$ & $\begin{array}{c}\text { Ca } \\
\text { wt. \% }\end{array}$ & $\begin{array}{c}\text { Fe } \\
\text { wt. \% }\end{array}$ & $\begin{array}{c}\text { K } \\
\text { wt. \% }\end{array}$ & $\begin{array}{c}\text { Mg } \\
\text { wt. \% }\end{array}$ & $\begin{array}{c}\mathrm{Na} \\
\text { wt. \% }\end{array}$ & $\begin{array}{c}\mathbf{P} \\
\text { wt. \% }\end{array}$ & $\begin{array}{c}\text { Ti } \\
\text { wt. \% }\end{array}$ & $\begin{array}{c}\mathrm{Ag} \\
\mathrm{ppm}\end{array}$ & $\begin{array}{c}\text { As } \\
\text { ppm }\end{array}$ & $\begin{array}{c}\text { Au } \\
\text { ppm }\end{array}$ & $\begin{array}{c}\text { Ba } \\
\text { ppm }\end{array}$ & $\begin{array}{c}\mathrm{Be} \\
\mathrm{ppm}\end{array}$ & $\begin{array}{c}\mathbf{B i} \\
\text { ppm }\end{array}$ \\
\hline SH-2/28-AD & 4.6 & 0.75 & 2.3 & 1.6 & 0.42 & 1.0 & 0.027 & 0.23 & $<2$ & $<10$ & $<8$ & 370 & 1.9 & $<10$ \\
\hline $\mathrm{SH}-2 / 29-\mathrm{AD}$ & 4.8 & 0.88 & 1.9 & 1.5 & 0.43 & 1.1 & 0.026 & 0.24 & $<2$ & $<10$ & $<8$ & 1100 & 2.1 & $<10$ \\
\hline $\mathrm{SH}-2 / 30-\mathrm{AD}$ & 4.8 & 0.83 & 1.5 & 1.7 & 0.40 & 1.2 & 0.024 & 0.19 & $<2$ & $<10$ & $<8$ & 1100 & 2.1 & $<10$ \\
\hline $\mathrm{SH}-2 / 31-\mathrm{AD}$ & 4.7 & 1.1 & 2.1 & 1.4 & 0.49 & 1.1 & 0.027 & 0.24 & $<2$ & $<10$ & $<8$ & 840 & 1.8 & $<10$ \\
\hline $\mathrm{SH}-2 / 32-\mathrm{AD}$ & 11.0 & 0.4 & 6.5 & 3.0 & 1.4 & 0.31 & 0.056 & 0.48 & $<2$ & $<10$ & $<8$ & 770 & 4.2 & $<10$ \\
\hline $\mathrm{SH}-2 / 33-\mathrm{AD}$ & 6.2 & 0.47 & 3.8 & 1.2 & 0.38 & 0.22 & 0.023 & 0.37 & $<2$ & $<10$ & $<8$ & 443 & 2.6 & $<10$ \\
\hline $\mathrm{SH}-2 / 34-\mathrm{AD}$ & 7.4 & 0.47 & 3.8 & 2.2 & 0.98 & 0.77 & 0.014 & 0.42 & $<2$ & 22 & $<8$ & 630 & 2.7 & $<10$ \\
\hline $\mathrm{SH}-2 / 35-\mathrm{AD}$ & 4.9 & 1.4 & 2.4 & 1.5 & 0.59 & 1.2 & 0.048 & 0.32 & $<2$ & $<10$ & $<8$ & 370 & 1.8 & $<10$ \\
\hline $\mathrm{SH}-2 / 36-\mathrm{AD}$ & 4.5 & 0.88 & 1.6 & 1.7 & 0.38 & 1.2 & 0.029 & 0.20 & $<2$ & $<10$ & $<8$ & 580 & 2.0 & $<10$ \\
\hline $\mathrm{SH}-2 / 37-\mathrm{AD}$ & 6.1 & 0.44 & 3.3 & 1.8 & 0.76 & 0.94 & 0.028 & 0.38 & $<2$ & $<10$ & $<8$ & 510 & 2.1 & $<10$ \\
\hline
\end{tabular}


Appendix 7. Results of ICP-AES analyses-Continued

\begin{tabular}{|c|c|c|c|c|c|c|c|c|c|c|c|c|c|c|c|}
\hline Sample & $\begin{array}{c}\text { Cd } \\
\text { ppm }\end{array}$ & $\begin{array}{c}\text { Ce } \\
\text { ppm }\end{array}$ & $\begin{array}{c}\text { Co } \\
\text { ppm }\end{array}$ & $\begin{array}{c}\mathrm{Cr} \\
\mathrm{ppm}\end{array}$ & $\begin{array}{c}\text { Cu } \\
\text { ppm }\end{array}$ & $\begin{array}{c}\text { Eu } \\
\text { ppm }\end{array}$ & $\begin{array}{c}\text { Ga } \\
\text { ppm }\end{array}$ & $\begin{array}{c}\text { Ho } \\
\text { ppm }\end{array}$ & $\begin{array}{c}\text { La } \\
\text { ppm }\end{array}$ & $\begin{array}{c}\text { Li } \\
\text { ppm }\end{array}$ & $\begin{array}{l}\text { Mn } \\
\text { ppm }\end{array}$ & $\begin{array}{c}\text { Mo } \\
\text { ppm }\end{array}$ & $\begin{array}{c}\mathrm{Nb} \\
\mathrm{ppm}\end{array}$ & $\begin{array}{c}\text { Nd } \\
\text { ppm }\end{array}$ & $\begin{array}{c}\mathrm{Ni} \\
\mathrm{ppm}\end{array}$ \\
\hline $\mathrm{SH}-2 / 1-\mathrm{AD}$ & $<2$ & 86 & 19 & 94 & 33 & $<2$ & 21 & $<4$ & 44 & 49 & 430 & 2 & 14 & 38 & 46 \\
\hline $\mathrm{SH}-2 / 2-\mathrm{AD}$ & $<2$ & 75 & 12 & 53 & 10 & $<2$ & 15 & $<4$ & 40 & 24 & 600 & $<2$ & 6.1 & 33 & 26 \\
\hline SH-2/3-AD & $<2$ & 86 & 17 & 97 & 36 & $<2$ & 14 & $<4$ & 42 & 36 & 840 & $<2$ & 16 & 42 & 45 \\
\hline SH-2/4-AD & $<2$ & 73 & 10 & 47 & 4.1 & $<2$ & 10 & $<4$ & 35 & 18 & 490 & $<2$ & 10 & 34 & 22 \\
\hline SH-2/5-AD & $<2$ & 80 & 7.7 & 43 & 3.5 & $<2$ & 9.3 & $<4$ & 39 & 16 & 500 & $<2$ & 11 & 37 & 18 \\
\hline $\mathrm{SH}-2 / 6-\mathrm{AD}$ & $<2$ & 66 & 8.3 & 40 & 4.5 & $<2$ & 9.1 & $<4$ & 33 & 17 & 470 & $<2$ & 11 & 30 & 19 \\
\hline $\mathrm{SH}-2 / 7-\mathrm{AD}$ & $<2$ & 56 & 5.9 & 28 & 6.8 & $<2$ & 6.9 & $<4$ & 27 & 12 & 390 & $<2$ & 7.9 & 24 & 12 \\
\hline SH-2/8-AD & $<2$ & 44 & 7.3 & 29 & 18 & $<2$ & 5.2 & $<4$ & 22 & 14 & 440 & $<2$ & 5.1 & 22 & 17 \\
\hline SH-2/9-AD & $<2$ & 70 & 21 & 110 & 52 & $<2$ & 17 & $<4$ & 34 & 56 & 470 & $<2$ & 18 & 34 & 60 \\
\hline $\mathrm{SH}-2 / 10-\mathrm{AD}$ & $<2$ & 29 & 48 & 12 & 10 & $<2$ & $<4$ & $<4$ & 14 & 12 & 2800 & $<2$ & $<4$ & 12 & 12 \\
\hline SH-2/11-AD & $<2$ & 54 & 5.3 & 24 & 2.1 & $<2$ & 8.4 & $<4$ & 26 & 14 & 350 & $<2$ & 9.3 & 26 & 11 \\
\hline $\mathrm{SH}-2 / 12-\mathrm{AD}$ & $<2$ & 36 & 16 & 90 & 22 & $<2$ & 18 & $<4$ & 19 & 31 & 510 & $<2$ & 15 & 17 & 42 \\
\hline $\mathrm{SH}-2 / 13-\mathrm{AD}$ & $<2$ & 69 & 7.8 & 46 & 4.3 & $<2$ & 9.4 & $<4$ & 33 & 14 & 300 & $<2$ & 11 & 33 & 20 \\
\hline SH-2/14-AD & $<2$ & 53 & 8.7 & 48 & 6 & $<2$ & 11 & $<4$ & 25 & 15 & 310 & $<2$ & 13 & 26 & 20 \\
\hline $\mathrm{SH}-2 / 15-\mathrm{AD}$ & $<2$ & 69 & 11 & 49 & 30 & $<2$ & $<4$ & $<4$ & 33 & 20 & 1100 & $<2$ & 8.4 & 31 & 23 \\
\hline SH-2/16-AD & $<2$ & 37 & 3.9 & 19 & 36 & $<2$ & 6.8 & $<4$ & 17 & 9.6 & 110 & $<2$ & 7.5 & 17 & 8.5 \\
\hline SH-2/17-AD & $<2$ & 55 & 8.2 & 36 & 4.8 & $<2$ & 11 & $<4$ & 25 & 16 & 260 & $<2$ & 11 & 24 & 18 \\
\hline SH-2/18-AD & $<2$ & 74 & 6.3 & 36 & 12 & $<2$ & 8.3 & $<4$ & 34 & 14 & 420 & $<2$ & 10 & 32 & 14 \\
\hline SH-2/19-AD & $<2$ & 56 & 7.8 & 32 & 6.2 & $<2$ & 7.6 & $<4$ & 27 & 16 & 490 & $<2$ & 9.8 & 25 & 17 \\
\hline $\mathrm{SH}-2 / 20-\mathrm{AD}$ & $<2$ & 44 & 5.2 & 19 & 3.5 & $<2$ & 9.3 & $<4$ & 21 & 12 & 240 & $<2$ & 11 & 18 & 12 \\
\hline SH-2/21-AD & $<2$ & 67 & 5.5 & 22 & 2.4 & $<2$ & 7.8 & $<4$ & 31 & 13 & 350 & $<2$ & 10 & 30 & 11 \\
\hline $\mathrm{SH}-2 / 22-\mathrm{AD}$ & $<2$ & 52 & 6.4 & 28 & 3.6 & $<2$ & 8.9 & $<4$ & 24 & 15 & 330 & $<2$ & 10 & 22 & 14 \\
\hline $\mathrm{SH}-2 / 23-\mathrm{AD}$ & $<2$ & 43 & 10 & 33 & 7.4 & $<2$ & 5.2 & $<4$ & 21 & 18 & 820 & $<2$ & 8.7 & 20 & 21 \\
\hline $\mathrm{SH}-2 / 24-\mathrm{AD}$ & $<2$ & 58 & 10 & 39 & 7.1 & $<2$ & 10 & $<4$ & 27 & 20 & 400 & $<2$ & 11 & 26 & 22 \\
\hline $\mathrm{SH}-2 / 25-\mathrm{AD}$ & $<2$ & 59 & 8 & 35 & 4.5 & $<2$ & 8.1 & $<4$ & 28 & 18 & 580 & $<2$ & 12 & 27 & 17 \\
\hline $\mathrm{SH}-2 / 26-\mathrm{AD}$ & $<2$ & 29 & 7.9 & 20 & 3.1 & $<2$ & $<4$ & $<4$ & 14 & 15 & 1300 & $<2$ & 6.2 & 14 & 12 \\
\hline SH-2/27-AD & $<2$ & 44 & 6.3 & 28 & 42 & $<2$ & 9.9 & $<4$ & 21 & 16 & 270 & $<2$ & 12 & 21 & 14 \\
\hline
\end{tabular}


Appendix 7. Results of ICP-AES analyses-Continued

\begin{tabular}{|c|c|c|c|c|c|c|c|c|c|c|c|c|c|c|c|}
\hline Sample & $\begin{array}{c}\text { Cd } \\
\text { ppm }\end{array}$ & $\begin{array}{c}\text { Ce } \\
\text { ppm }\end{array}$ & $\begin{array}{c}\text { Co } \\
\text { ppm }\end{array}$ & $\begin{array}{c}\mathrm{Cr} \\
\mathrm{ppm}\end{array}$ & $\begin{array}{c}\text { Cu } \\
\text { ppm }\end{array}$ & $\begin{array}{c}\text { Eu } \\
\text { ppm }\end{array}$ & $\begin{array}{c}\text { Ga } \\
\text { ppm }\end{array}$ & $\begin{array}{c}\text { Ho } \\
\text { ppm }\end{array}$ & $\begin{array}{c}\text { La } \\
\text { ppm }\end{array}$ & $\begin{array}{c}\text { Li } \\
\text { ppm }\end{array}$ & $\begin{array}{c}\text { Mn } \\
\text { ppm }\end{array}$ & $\begin{array}{l}\text { Mo } \\
\text { ppm }\end{array}$ & $\begin{array}{c}\mathrm{Nb} \\
\mathrm{ppm}\end{array}$ & $\begin{array}{c}\text { Nd } \\
\text { ppm }\end{array}$ & $\begin{array}{c}\mathrm{Ni} \\
\mathrm{ppm}\end{array}$ \\
\hline SH-2/28-AD & $<2$ & 73 & 7.0 & 36 & 2.3 & $<2$ & $<4$ & $<4$ & 34 & 15 & 980 & $<2$ & 7.1 & 34 & 13 \\
\hline SH-2/29-AD & $<2$ & 82 & 6.1 & 36 & 6.6 & $<2$ & 6.7 & $<4$ & 39 & 14 & 580 & $<2$ & 9.1 & 36 & 12 \\
\hline $\mathrm{SH}-2 / 30-\mathrm{AD}$ & $<2$ & 49 & 2.4 & 29 & 3.1 & $<2$ & 9.6 & $<4$ & 26 & 16 & 320 & $<2$ & 6.1 & 20 & 12 \\
\hline $\mathrm{SH}-2 / 31-\mathrm{AD}$ & $<2$ & 86 & 3.8 & 40 & 4.7 & $<2$ & 9.7 & $<4$ & 46 & 14 & 650 & $<2$ & $<4$ & 34 & 11 \\
\hline $\mathrm{SH}-2 / 32-\mathrm{AD}$ & $<2$ & 79 & 24 & 80 & 41 & 2 & 30 & $<4$ & 41 & 67 & 610 & 3.4 & 19 & 36 & 54 \\
\hline $\mathrm{SH}-2 / 33-\mathrm{AD}$ & $<2$ & 87 & 13 & 77 & 34 & $<2$ & 14 & $<4$ & 40 & 46 & 1100 & $<2$ & $<4$ & 34 & 31 \\
\hline $\mathrm{SH}-2 / 34-\mathrm{AD}$ & $<2$ & 73 & 16 & 77 & 76 & $<2$ & 15 & $<4$ & 38 & 32 & 340 & 2.2 & 16 & 32 & 37 \\
\hline $\mathrm{SH}-2 / 35-\mathrm{AD}$ & $<2$ & 110 & 6.6 & 38 & 3.2 & $<2$ & 10 & $<4$ & 58 & 14 & 680 & $<2$ & $<4$ & 44 & 13 \\
\hline $\mathrm{SH}-2 / 36-\mathrm{AD}$ & $<2$ & 67 & 4.0 & 29 & 3.0 & $<2$ & 9 & $<4$ & 36 & 15 & 390 & $<2$ & $<4$ & 28 & 10 \\
\hline SH-2/37-AD & $<2$ & 73 & 16 & 73 & 61 & $<2$ & 17 & $<4$ & 38 & 37 & 750 & $<2$ & 7.1 & 32 & 38 \\
\hline
\end{tabular}


Appendix 7. Results of ICP-AES analyses-Continued

\begin{tabular}{|c|c|c|c|c|c|c|c|c|c|c|c|}
\hline Sample & $\begin{array}{c}\mathrm{Pb} \\
\mathrm{ppm}\end{array}$ & $\begin{array}{c}\text { Sc } \\
\text { ppm }\end{array}$ & $\begin{array}{c}\text { Sn } \\
\text { ppm }\end{array}$ & $\begin{array}{c}\mathrm{Sr} \\
\mathrm{ppm}\end{array}$ & $\begin{array}{c}\text { Ta } \\
\text { ppm }\end{array}$ & $\begin{array}{c}\text { Th } \\
\text { ppm }\end{array}$ & $\begin{array}{c}\mathbf{U} \\
\mathbf{p p m}\end{array}$ & $\begin{array}{c}\mathbf{V} \\
\mathrm{ppm}\end{array}$ & $\begin{array}{c}\mathrm{Y} \\
\mathrm{ppm}\end{array}$ & $\begin{array}{c}\text { Yb } \\
\text { ppm }\end{array}$ & $\begin{array}{c}\mathrm{Zn} \\
\mathrm{ppm}\end{array}$ \\
\hline SH-2/1-AD & 25 & 14 & $<5$ & 110 & $<20$ & 21 & $<100$ & 100 & 21 & 2.3 & 83 \\
\hline SH-2/2-AD & 17 & 9.4 & $<5$ & 140 & $<20$ & 17 & $<100$ & 66 & 21 & 2.4 & 48 \\
\hline SH-2/3-AD & 25 & 15 & $<5$ & 140 & $<20$ & $\mathrm{nr}$ & $<100$ & 100 & 23 & 2.4 & 91 \\
\hline SH-2/4-AD & 21 & 9.2 & $<5$ & 150 & $<20$ & $\mathrm{nr}$ & $<100$ & 60 & 19 & 2.0 & 44 \\
\hline SH-2/5-AD & 18 & 8.6 & $<5$ & 160 & $<20$ & $\mathrm{nr}$ & $<100$ & 55 & 21 & 2.3 & 38 \\
\hline SH-2/6-AD & 19 & 7.6 & $<5$ & 150 & $<20$ & $\mathrm{nr}$ & $<100$ & 48 & 16 & 1.8 & 40 \\
\hline SH-2/7-AD & 18 & 5.8 & $<5$ & 150 & $<20$ & $\mathrm{nr}$ & $<100$ & 34 & 13 & 1.5 & 28 \\
\hline SH-2/8-AD & 13 & 4.7 & $<5$ & 78 & $<20$ & $\mathrm{nr}$ & $<100$ & 30 & 10 & 1.2 & 34 \\
\hline SH-2/9-AD & 39 & 16 & $<5$ & 130 & $<20$ & $\mathrm{nr}$ & $<100$ & 120 & 20 & 2.2 & 110 \\
\hline SH-2/10-AD & 9.4 & 3.9 & $<5$ & 76 & $<20$ & $\mathrm{nr}$ & $<100$ & 22 & 7.6 & $<1$ & 30 \\
\hline $\mathrm{SH}-2 / 11-\mathrm{AD}$ & 17 & 5.4 & $<5$ & 150 & $<20$ & $\mathrm{nr}$ & $<100$ & 34 & 13 & 1.4 & 31 \\
\hline $\mathrm{SH}-2 / 12-\mathrm{AD}$ & 24 & 12 & $<5$ & 120 & $<20$ & $\mathrm{nr}$ & $<100$ & 85 & 14 & 1.5 & 96 \\
\hline $\mathrm{SH}-2 / 13-\mathrm{AD}$ & 18 & 7.3 & $<5$ & 120 & $<20$ & $\mathrm{nr}$ & $<100$ & 57 & 18 & 1.8 & 32 \\
\hline $\mathrm{SH}-2 / 14-\mathrm{AD}$ & 20 & 7.7 & $<5$ & 130 & $<20$ & $\mathrm{nr}$ & $<100$ & 52 & 15 & 1.5 & 46 \\
\hline $\mathrm{SH}-2 / 15-\mathrm{AD}$ & 19 & 7.9 & $<5$ & 90 & $<20$ & $\mathrm{nr}$ & $<100$ & 56 & 17 & 1.8 & 76 \\
\hline $\mathrm{SH}-2 / 16-\mathrm{AD}$ & 19 & 3.2 & $<5$ & 100 & $<20$ & $\mathrm{nr}$ & $<100$ & 23 & 8.9 & $<1$ & 77 \\
\hline SH-2/17-AD & 23 & 6.2 & $<5$ & 140 & $<20$ & $\mathrm{nr}$ & $<100$ & 44 & 14 & 1.6 & 34 \\
\hline SH-2/18-AD & 21 & 7.6 & $<5$ & 140 & $<20$ & $\mathrm{nr}$ & $<100$ & 50 & 19 & 2.2 & 73 \\
\hline SH-2/19-AD & 19 & 6.2 & $<5$ & 120 & $<20$ & $\mathrm{nr}$ & $<100$ & 42 & 14 & 1.6 & 38 \\
\hline $\mathrm{SH}-2 / 20-\mathrm{AD}$ & 22 & 4.9 & $<5$ & 130 & $<20$ & $\mathrm{nr}$ & $<100$ & 33 & 12 & 1.3 & 33 \\
\hline SH-2/21-AD & 19 & 5.6 & $<5$ & 120 & $<20$ & $\mathrm{nr}$ & $<100$ & 36 & 16 & 1.8 & 25 \\
\hline $\mathrm{SH}-2 / 22-\mathrm{AD}$ & 21 & 5.7 & $<5$ & 120 & $<20$ & $\mathrm{nr}$ & $<100$ & 38 & 12 & 1.3 & 29 \\
\hline $\mathrm{SH}-2 / 23-\mathrm{AD}$ & 22 & 6.4 & $<5$ & 120 & $<20$ & $\mathrm{nr}$ & $<100$ & 40 & 11 & 1.3 & 74 \\
\hline $\mathrm{SH}-2 / 24-\mathrm{AD}$ & 19 & 7.7 & $<5$ & 130 & $<20$ & $\mathrm{nr}$ & $<100$ & 52 & 15 & 1.6 & 49 \\
\hline $\mathrm{SH}-2 / 25-\mathrm{AD}$ & 19 & 7.3 & $<5$ & 130 & $<20$ & $\mathrm{nr}$ & $<100$ & 50 & 16 & 1.6 & 39 \\
\hline $\mathrm{SH}-2 / 26-\mathrm{AD}$ & 18 & 4.5 & $<5$ & 110 & $<20$ & $\mathrm{nr}$ & $<100$ & 28 & 8.2 & $<1$ & 30 \\
\hline SH-2/27-AD & 21 & 5.1 & $<5$ & 130 & $<20$ & $\mathrm{nr}$ & $<100$ & 35 & 11 & 1.2 & 51 \\
\hline
\end{tabular}


Appendix 7. Results of ICP-AES analyses-Continued

\begin{tabular}{|c|c|c|c|c|c|c|c|c|c|c|c|}
\hline Sample & $\begin{array}{c}\mathrm{Pb} \\
\mathrm{ppm}\end{array}$ & $\begin{array}{c}\text { Sc } \\
\text { ppm }\end{array}$ & $\begin{array}{c}\text { Sn } \\
\text { ppm }\end{array}$ & $\begin{array}{c}\text { Sr } \\
\text { ppm }\end{array}$ & $\begin{array}{c}\text { Ta } \\
\text { ppm }\end{array}$ & $\begin{array}{c}\text { Th } \\
\text { ppm }\end{array}$ & $\begin{array}{c}\mathbf{U} \\
\mathrm{ppm}\end{array}$ & $\begin{array}{c}\mathbf{V} \\
\mathrm{ppm}\end{array}$ & $\begin{array}{c}Y \\
\mathrm{ppm}\end{array}$ & $\begin{array}{c}\text { Yb } \\
\text { ppm }\end{array}$ & $\begin{array}{c}\mathrm{Zn} \\
\mathrm{ppm}\end{array}$ \\
\hline SH-2/28-AD & 17 & 7.0 & $<5$ & 120 & $<20$ & $\mathrm{nr}$ & $<100$ & 45 & 18 & 2.0 & 29 \\
\hline $\mathrm{SH}-2 / 29-\mathrm{AD}$ & 18 & 7.6 & $<5$ & 140 & $<20$ & $\mathrm{nr}$ & $<100$ & 48 & 21 & 2.5 & 34 \\
\hline $\mathrm{SH}-2 / 30-\mathrm{AD}$ & 18 & 5.6 & 23 & 160 & $<20$ & 10 & $<100$ & 40 & 12 & 1.3 & 26 \\
\hline $\mathrm{SH}-2 / 31-\mathrm{AD}$ & 15 & 8.3 & 6.7 & 150 & $<20$ & 18 & $<100$ & 50 & 22 & 3.0 & 28 \\
\hline $\mathrm{SH}-2 / 32-\mathrm{AD}$ & 34 & 18 & 5.4 & 92 & $<20$ & 25 & $<100$ & 140 & 22 & 2.5 & 120 \\
\hline SH-2/33-AD & 24 & 11 & 30 & 51 & $<20$ & 20 & $<100$ & 100 & 19 & 2.1 & 48 \\
\hline SH-2/34-AD & 26 & 12 & 8 & 93 & $<20$ & 17 & $<100$ & 87 & 19 & 2.2 & 110 \\
\hline $\mathrm{SH}-2 / 35-\mathrm{AD}$ & 16 & 9.3 & 16 & 140 & $<20$ & 24 & $<100$ & 61 & 29 & 3.6 & 32 \\
\hline $\mathrm{SH}-2 / 36-\mathrm{AD}$ & 19 & 5.8 & $<5$ & 130 & $<20$ & 14 & $<100$ & 39 & 16 & 1.8 & 24 \\
\hline SH-2/37-AD & 24 & 9.6 & $<5$ & 91 & $<20$ & 16 & $<100$ & 71 & 16 & 1.8 & 94 \\
\hline
\end{tabular}


Appendix 8. Results of Energy Dispersive X-ray Fluorescence (EDXRF) analyses of air-dried sediment samples recovered from the SH2 borehole at Rajoir, Bangladesh.

[David Siems and Tammy Hannah, USGS, Analysts; wt.\% weight percent; ppm, parts per million]

\begin{tabular}{|c|c|c|c|c|c|c|c|c|c|c|c|c|c|}
\hline Sample & $\begin{array}{c}\mathrm{Ag} \\
\mathrm{ppm}\end{array}$ & $\begin{array}{c}\text { As } \\
\text { ppm }\end{array}$ & $\begin{array}{c}\mathrm{Ba} \\
\mathrm{ppm}\end{array}$ & $\begin{array}{c}\mathbf{B i} \\
\mathrm{ppm}\end{array}$ & $\begin{array}{c}\mathrm{Br} \\
\mathrm{ppm}\end{array}$ & $\begin{array}{c}\text { Cd } \\
\text { ppm }\end{array}$ & $\begin{array}{c}\text { Ce } \\
\text { ppm }\end{array}$ & $\begin{array}{c}\mathrm{Cr} \\
\mathrm{ppm}\end{array}$ & $\begin{array}{c}\text { Cs } \\
\text { ppm }\end{array}$ & $\begin{array}{c}\mathrm{Cu} \\
\mathrm{ppm}\end{array}$ & $\begin{array}{c}\mathrm{Ga} \\
\mathrm{ppm}\end{array}$ & $\begin{array}{c}\mathrm{Ge} \\
\mathrm{ppm}\end{array}$ & $\begin{array}{c}\text { La } \\
\text { ppm }\end{array}$ \\
\hline SH-2/1-AD & $<1$ & 3 & 530 & $<5$ & 6 & $<1$ & 90 & 90 & 11 & 37 & 19 & $<2$ & 45 \\
\hline SH-2/2-AD & $<1$ & 2 & 400 & $<5$ & $<1$ & $<1$ & 93 & 53 & 6 & 19 & 15 & $<2$ & 48 \\
\hline SH-2/3-AD & $<1$ & 3 & 520 & $<5$ & $<1$ & $<1$ & 86 & 97 & 10 & 51 & 17 & $<2$ & 43 \\
\hline SH-2/4-AD & $<1$ & $<2$ & 410 & $<5$ & $<1$ & $<1$ & 71 & 46 & 8 & 19 & 12 & $<2$ & 38 \\
\hline SH-2/5-AD & $<1$ & $<2$ & 390 & $<5$ & $<1$ & $<1$ & 80 & 47 & 7 & 20 & 12 & $<2$ & 43 \\
\hline SH-2/6-AD & $<1$ & $<2$ & 410 & $<5$ & $<1$ & $<1$ & 71 & 37 & 8 & 19 & 12 & $<2$ & 40 \\
\hline SH-2/7-AD & $<1$ & $<2$ & 360 & $<5$ & $<1$ & $<1$ & 60 & 28 & 5 & 20 & 9 & $<2$ & 36 \\
\hline SH-2/8-AD & $<1$ & $<2$ & 290 & $<5$ & $<1$ & $<1$ & 47 & 29 & $<5$ & 41 & 6 & $<2$ & 28 \\
\hline SH-2/9-AD & $<1$ & 9 & 580 & $<5$ & 1 & $<1$ & 71 & 110 & 15 & 65 & 20 & $<2$ & 36 \\
\hline $\mathrm{SH}-2 / 10-\mathrm{AD}$ & $<1$ & $<2$ & 250 & $<5$ & $<1$ & $<1$ & 29 & 17 & $<5$ & 47 & 7 & 4 & 15 \\
\hline SH-2/11-AD & $<1$ & $<2$ & 380 & $<5$ & $<1$ & $<1$ & 54 & 24 & $<5$ & 18 & 10 & $<2$ & 32 \\
\hline $\mathrm{SH}-2 / 12-\mathrm{AD}$ & $<1$ & $<2$ & 530 & $<5$ & 1 & $<1$ & 35 & 84 & 18 & 37 & 18 & $<2$ & 19 \\
\hline $\mathrm{SH}-2 / 13-\mathrm{AD}$ & $<1$ & $<2$ & 390 & $<5$ & $<1$ & $<1$ & 71 & 42 & 6 & 21 & 11 & $<2$ & 39 \\
\hline SH-2/14-AD & $<1$ & $<2$ & 440 & $<5$ & 1 & $<1$ & 58 & 43 & 8 & 21 & 10 & $<2$ & 30 \\
\hline $\mathrm{SH}-2 / 15-\mathrm{AD}$ & $<1$ & 3 & 390 & $<5$ & 2 & $<1$ & 73 & 52 & 6 & 47 & 13 & $<2$ & 37 \\
\hline SH-2/16-AD & $<1$ & $<2$ & 420 & $<5$ & $<1$ & $<1$ & 61 & 20 & 7 & 48 & 8 & $<2$ & 34 \\
\hline SH-2/17-AD & $<1$ & $<2$ & 420 & $<5$ & $<1$ & $<1$ & 57 & 34 & 8 & 20 & 12 & $<2$ & 33 \\
\hline SH-2/18-AD & $<1$ & $<2$ & 410 & $<5$ & $<1$ & $<1$ & 74 & 36 & 5 & 27 & 11 & $<2$ & 41 \\
\hline SH-2/19-AD & $<1$ & $<2$ & 420 & $<5$ & $<1$ & $<1$ & 61 & 35 & 9 & 25 & 10 & $<2$ & 34 \\
\hline $\mathrm{SH}-2 / 20-\mathrm{AD}$ & $<1$ & $<2$ & 470 & $<5$ & $<1$ & $<1$ & 73 & 28 & 7 & 18 & 9 & $<2$ & 41 \\
\hline SH-2/21-AD & $<1$ & $<2$ & 480 & $<5$ & $<1$ & $<1$ & 73 & 29 & 5 & 19 & 9 & $<2$ & 41 \\
\hline $\mathrm{SH}-2 / 22-\mathrm{AD}$ & $<1$ & $<2$ & 580 & $<5$ & $<1$ & $<1$ & 61 & 33 & 7 & 18 & 10 & $<2$ & 35 \\
\hline $\mathrm{SH}-2 / 23-\mathrm{AD}$ & $<1$ & 2 & 530 & $<5$ & $<1$ & $<1$ & 49 & 33 & 6 & 26 & 11 & $<2$ & 26 \\
\hline $\mathrm{SH}-2 / 24-\mathrm{AD}$ & $<1$ & $<2$ & 590 & $<5$ & $<1$ & $<1$ & 63 & 42 & 11 & 23 & 12 & $<2$ & 34 \\
\hline $\mathrm{SH}-2 / 25-\mathrm{AD}$ & $<1$ & $<2$ & 440 & $<5$ & $<1$ & $<1$ & 34 & 23 & 7 & 18 & 8 & $<2$ & 22 \\
\hline $\mathrm{SH}-2 / 26-\mathrm{AD}$ & $<1$ & $<2$ & 440 & $<5$ & $<1$ & $<1$ & 32 & 23 & $<5$ & 19 & 10 & $<2$ & 21 \\
\hline SH-2/27-AD & $<1$ & $<2$ & 650 & $<5$ & $<1$ & $<1$ & 50 & 30 & 10 & 51 & 10 & $<2$ & 30 \\
\hline
\end{tabular}


Appendix 8. Results of EDXRF analyses-Continued.

\begin{tabular}{|c|c|c|c|c|c|c|c|c|c|c|c|c|c|}
\hline Sample & $\begin{array}{c}\mathrm{Ag} \\
\mathrm{ppm}\end{array}$ & $\begin{array}{c}\text { As } \\
\text { ppm }\end{array}$ & $\begin{array}{c}\text { Ba } \\
\text { ppm }\end{array}$ & $\begin{array}{c}\mathrm{Bi} \\
\mathrm{ppm}\end{array}$ & $\begin{array}{c}\mathrm{Br} \\
\mathrm{ppm}\end{array}$ & $\begin{array}{c}\text { Cd } \\
\text { ppm }\end{array}$ & $\begin{array}{c}\text { Ce } \\
\text { ppm }\end{array}$ & $\begin{array}{c}\mathrm{Cr} \\
\mathrm{ppm}\end{array}$ & $\begin{array}{c}\text { Cs } \\
\text { ppm }\end{array}$ & $\begin{array}{c}\mathrm{Cu} \\
\mathrm{ppm}\end{array}$ & $\begin{array}{c}\mathrm{Ga} \\
\mathrm{ppm}\end{array}$ & $\begin{array}{c}\mathrm{Ge} \\
\mathrm{ppm}\end{array}$ & $\begin{array}{c}\text { La } \\
\text { ppm }\end{array}$ \\
\hline SH-2/28-AD & $<1$ & $<2$ & 420 & $<5$ & 1 & $<1$ & 85 & 40 & 8 & 19 & 10 & $<2$ & 45 \\
\hline $\mathrm{SH}-2 / 29-\mathrm{AD}$ & $<1$ & $<2$ & 1200 & $<5$ & $<1$ & $<1$ & 90 & 43 & 12 & 22 & 11 & $<2$ & 53 \\
\hline SH-2/30-AD & $<1$ & $<2$ & 1200 & $<5$ & $<1$ & $<1$ & 64 & 31 & 14 & 9 & 10 & $<2$ & 40 \\
\hline $\mathrm{SH}-2 / 31-\mathrm{AD}$ & $<1$ & $<2$ & 910 & $<5$ & $<1$ & $<1$ & 100 & 36 & 9 & 11 & 11 & $<2$ & 59 \\
\hline $\mathrm{SH}-2 / 32-\mathrm{AD}$ & $<1$ & 6 & 660 & $<5$ & $<1$ & $<1$ & 78 & 120 & 18 & 45 & 24 & $<2$ & 42 \\
\hline SH-2/33-AD & $<1$ & 4 & 420 & $<5$ & $<1$ & $<1$ & 110 & 75 & 9 & 41 & 16 & $<2$ & 47 \\
\hline $\mathrm{SH}-2 / 34-\mathrm{AD}$ & $<1$ & 21 & 610 & $<5$ & $<1$ & $<1$ & 89 & 85 & 11 & 74 & 18 & $<2$ & 45 \\
\hline SH-2/35-AD & $<1$ & $<2$ & 370 & $<5$ & $<1$ & $<1$ & 130 & 36 & 5 & 12 & 11 & $<2$ & 66 \\
\hline $\mathrm{SH}-2 / 36-\mathrm{AD}$ & $<1$ & $<2$ & 500 & $<5$ & $<1$ & $<1$ & 87 & 87 & 7 & 64 & 13 & $<2$ & 43 \\
\hline SH-2/37-AD & $<1$ & 7 & 420 & $<5$ & 1 & $<1$ & 85 & 40 & 8 & 19 & 10 & $<2$ & 45 \\
\hline
\end{tabular}


Appendix 8. Results of EDXRF analyses-Continued.

\begin{tabular}{|c|c|c|c|c|c|c|c|c|c|c|c|c|}
\hline Sample & $\begin{array}{l}\text { Mo } \\
\text { ppm }\end{array}$ & $\begin{array}{c}\mathbf{N b} \\
\mathbf{p p m}\end{array}$ & $\begin{array}{c}\mathbf{N d} \\
\text { ppm }\end{array}$ & $\begin{array}{c}\mathrm{Ni} \\
\mathbf{p p m}\end{array}$ & $\begin{array}{c}\mathrm{Pb} \\
\mathrm{ppm}\end{array}$ & $\begin{array}{c}\mathbf{R b} \\
\mathbf{p p m}\end{array}$ & $\begin{array}{c}\text { Sb } \\
\text { ppm }\end{array}$ & $\begin{array}{c}\text { Se } \\
\text { ppm }\end{array}$ & $\begin{array}{c}\text { Sn } \\
\text { ppm }\end{array}$ & $\begin{array}{c}\mathrm{Sr} \\
\mathrm{ppm}\end{array}$ & $\begin{array}{c}\text { Th } \\
\text { ppm }\end{array}$ & $\begin{array}{c}\mathbf{U} \\
\mathbf{p p m}\end{array}$ \\
\hline SH-2/1-AD & $<2$ & 16 & 40 & 53 & 25 & 180 & $<2$ & $<1$ & 5 & 110 & 19 & $<4$ \\
\hline SH-2/2-AD & $<2$ & 12 & 44 & 37 & 19 & 110 & $<2$ & $<1$ & 3 & 140 & 16 & $<4$ \\
\hline SH-2/3-AD & $<2$ & 16 & 30 & 54 & 25 & 150 & $<2$ & $<1$ & 5 & 140 & 19 & $<4$ \\
\hline SH-2/4-AD & $<2$ & 10 & 26 & 32 & 19 & 110 & $<2$ & $<1$ & 3 & 170 & 9 & 5 \\
\hline SH-2/5-AD & $<2$ & 10 & 29 & 30 & 17 & 95 & $<2$ & $<1$ & 3 & 170 & 15 & $<4$ \\
\hline SH-2/6-AD & $<2$ & 8 & 32 & 28 & 18 & 100 & $<2$ & $<1$ & 2 & 170 & 10 & $<4$ \\
\hline SH-2/7-AD & $<2$ & 6 & 33 & 21 & 16 & 78 & $<2$ & $<1$ & $<2$ & 160 & 9 & $<4$ \\
\hline SH-2/8-AD & $<2$ & 6 & 22 & 20 & 14 & 70 & $<2$ & $<1$ & $<2$ & 89 & 9 & 4 \\
\hline SH-2/9-AD & $<2$ & 14 & 36 & 71 & 37 & 170 & $<2$ & $<1$ & 4 & 140 & 18 & 5 \\
\hline SH-2/10-AD & $<2$ & 5 & $<10$ & 23 & 13 & 65 & $<2$ & $<1$ & 2 & 83 & 5 & $<4$ \\
\hline SH-2/11-AD & $<2$ & 6 & 16 & 19 & 18 & 88 & $<2$ & $<1$ & 2 & 160 & 9 & $<4$ \\
\hline SH-2/12-AD & $<2$ & 13 & 16 & 50 & 22 & 210 & $<2$ & $<1$ & 5 & 120 & 5 & $<4$ \\
\hline SH-2/13-AD & $<2$ & 9 & 30 & 26 & 17 & 87 & $<2$ & $<1$ & 2 & 140 & 11 & $<4$ \\
\hline SH-2/14-AD & $<2$ & 9 & 26 & 28 & 19 & 110 & $<2$ & $<1$ & 3 & 140 & 9 & $<4$ \\
\hline SH-2/15-AD & $<2$ & 10 & 34 & 36 & 18 & 100 & $<2$ & $<1$ & 3 & 110 & 13 & 4 \\
\hline SH-2/16-AD & 2 & 5 & 44 & 14 & 19 & 88 & $<2$ & $<1$ & 2 & 110 & 8 & 6 \\
\hline SH-2/17-AD & $<2$ & 8 & 26 & 24 & 18 & 100 & $<2$ & $<1$ & 2 & 150 & 6 & $<4$ \\
\hline SH-2/18-AD & $<2$ & 9 & 27 & 24 & 18 & 87 & $<2$ & $<1$ & 2 & 160 & 13 & $<4$ \\
\hline SH-2/19-AD & $<2$ & 7 & 32 & 24 & 18 & 100 & $<2$ & $<1$ & 2 & 140 & 9 & $<4$ \\
\hline SH-2/20-AD & $<2$ & 8 & 36 & 18 & 18 & 85 & $<2$ & $<1$ & $<2$ & 140 & 14 & 4 \\
\hline SH-2/21-AD & $<2$ & 7 & 29 & 23 & 17 & 84 & $<2$ & $<1$ & $<2$ & 140 & 11 & $<4$ \\
\hline SH-2/22-AD & $<2$ & 7 & 30 & 22 & 18 & 93 & $<2$ & $<1$ & 2 & 140 & 8 & $<4$ \\
\hline SH-2/23-AD & $<2$ & 7 & 24 & 31 & 23 & 110 & $<2$ & $<1$ & 2 & 130 & 7 & $<4$ \\
\hline SH-2/24-AD & $<2$ & 10 & 30 & 36 & 20 & 120 & $<2$ & $<1$ & 3 & 140 & 13 & 7 \\
\hline SH-2/25-AD & $<2$ & 6 & 14 & 21 & 18 & 100 & $<2$ & $<1$ & $<2$ & 120 & 5 & $<4$ \\
\hline SH-2/26-AD & $<2$ & 6 & 15 & 23 & 19 & 100 & $<2$ & $<1$ & 2 & 120 & 6 & $<4$ \\
\hline SH-2/27-AD & $<2$ & 6 & 22 & 19 & 18 & 98 & $<2$ & $<1$ & 3 & 140 & 7 & $<4$ \\
\hline
\end{tabular}


Appendix 8. Results of EDXRF analyses-Continued.

\begin{tabular}{|c|c|c|c|c|c|c|c|c|c|c|c|c|}
\hline Sample & $\begin{array}{c}\text { Mo } \\
\text { ppm }\end{array}$ & $\begin{array}{c}\mathrm{Nb} \\
\mathrm{ppm}\end{array}$ & $\begin{array}{c}\text { Nd } \\
\text { ppm }\end{array}$ & $\begin{array}{c}\mathrm{Ni} \\
\mathrm{ppm}\end{array}$ & $\begin{array}{c}\mathrm{Pb} \\
\mathrm{ppm}\end{array}$ & $\begin{array}{c}\text { Rb } \\
\text { ppm }\end{array}$ & $\begin{array}{c}\text { Sb } \\
\text { ppm }\end{array}$ & $\begin{array}{c}\text { Se } \\
\text { ppm }\end{array}$ & $\begin{array}{c}\text { Sn } \\
\text { ppm }\end{array}$ & $\begin{array}{c}\mathrm{Sr} \\
\mathrm{ppm}\end{array}$ & $\begin{array}{c}\text { Th } \\
\text { ppm }\end{array}$ & $\begin{array}{c}\mathbf{U} \\
\mathrm{ppm}\end{array}$ \\
\hline $\mathrm{SH}-2 / 28-\mathrm{AD}$ & $<2$ & 9 & 40 & 25 & 17 & 88 & $<2$ & $<1$ & 2 & 130 & 15 & 6 \\
\hline SH-2/29-AD & $<2$ & 9 & 46 & 25 & 16 & 77 & $<2$ & $<1$ & 3 & 160 & 13 & $<4$ \\
\hline $\mathrm{SH}-2 / 30-\mathrm{AD}$ & 2 & 8 & 37 & 20 & 19 & 89 & $<2$ & $<1$ & 2 & 160 & 9 & $<4$ \\
\hline $\mathrm{SH}-2 / 31-\mathrm{AD}$ & $<2$ & 8 & 43 & 24 & 16 & 69 & $<2$ & $<1$ & 3 & 160 & 16 & $<4$ \\
\hline $\mathrm{SH}-2 / 32-\mathrm{AD}$ & 2 & 19 & 32 & 61 & 36 & 200 & $<2$ & $<1$ & 6 & 90 & 24 & 7 \\
\hline $\mathrm{SH}-2 / 33-\mathrm{AD}$ & $<2$ & 16 & 35 & 45 & 24 & 100 & $<2$ & $<1$ & 4 & 54 & 19 & 6 \\
\hline $\mathrm{SH}-2 / 34-\mathrm{AD}$ & $<2$ & 17 & 48 & 47 & 26 & 130 & $<2$ & $<1$ & 5 & 97 & 19 & 6 \\
\hline $\mathrm{SH}-2 / 35-\mathrm{AD}$ & $<2$ & 12 & 47 & 22 & 16 & 76 & $<2$ & $<1$ & 3 & 150 & 22 & 5 \\
\hline $\mathrm{SH}-2 / 36-\mathrm{AD}$ & $<2$ & 16 & 41 & 49 & 19 & 110 & $<2$ & $<1$ & 4 & 96 & 15 & $<4$ \\
\hline SH-2/37-AD & $<2$ & 9 & 40 & 25 & 17 & 88 & $<2$ & $<1$ & 2 & 130 & 15 & 6 \\
\hline
\end{tabular}


Appendix 8. Results of EDXRF analyses-Continued.

\begin{tabular}{|c|c|c|c|c|c|}
\hline Sample & $\begin{array}{c}\mathrm{V} \\
\mathrm{ppm}\end{array}$ & $\begin{array}{c}\mathrm{W} \\
\mathrm{ppm}\end{array}$ & $\begin{array}{c}Y \\
\text { ppm }\end{array}$ & $\begin{array}{c}\mathrm{Zn} \\
\mathrm{ppm}\end{array}$ & $\begin{array}{c}\mathrm{Zr} \\
\mathrm{ppm}\end{array}$ \\
\hline SH-2/1-AD & 110 & $<5$ & 35 & 84 & 108 \\
\hline SH-2/2-AD & 71 & $<5$ & 33 & 55 & 71 \\
\hline SH-2/3-AD & 110 & $<5$ & 35 & 83 & 107 \\
\hline SH-2/4-AD & 56 & $<5$ & 25 & 48 & 56 \\
\hline SH-2/5-AD & 53 & $<5$ & 26 & 41 & 53 \\
\hline SH-2/6-AD & 45 & $<5$ & 19 & 43 & 45 \\
\hline SH-2/7-AD & 33 & $<5$ & 17 & 33 & 33 \\
\hline SH-2/8-AD & 28 & $<5$ & 16 & 46 & 28 \\
\hline SH-2/9-AD & 110 & $<5$ & 27 & 103 & 113 \\
\hline SH-2/10-AD & 24 & 160 & 12 & 49 & 24 \\
\hline SH-2/11-AD & 30 & $<5$ & 16 & 35 & 30 \\
\hline SH-2/12-AD & 91 & $<5$ & 17 & 93 & 91 \\
\hline $\mathrm{SH}-2 / 13-\mathrm{AD}$ & 55 & $<5$ & 21 & 34 & 55 \\
\hline $\mathrm{SH}-2 / 14-\mathrm{AD}$ & 53 & $<5$ & 18 & 50 & 53 \\
\hline SH-2/15-AD & 62 & $<5$ & 26 & 78 & 62 \\
\hline $\mathrm{SH}-2 / 16-\mathrm{AD}$ & 24 & $<5$ & 15 & 81 & 24 \\
\hline SH-2/17-AD & 43 & $<5$ & 18 & 36 & 43 \\
\hline SH-2/18-AD & 52 & $<5$ & 25 & 77 & 52 \\
\hline SH-2/19-AD & 41 & $<5$ & 17 & 40 & 41 \\
\hline SH-2/20-AD & 34 & $<5$ & 22 & 30 & 34 \\
\hline $\mathrm{SH}-2 / 21-\mathrm{AD}$ & 37 & $<5$ & 19 & 30 & 37 \\
\hline $\mathrm{SH}-2 / 22-\mathrm{AD}$ & 36 & $<5$ & 16 & 33 & 36 \\
\hline $\mathrm{SH}-2 / 23-\mathrm{AD}$ & 41 & $<5$ & 14 & 78 & 41 \\
\hline $\mathrm{SH}-2 / 24-\mathrm{AD}$ & 51 & $<5$ & 23 & 54 & 51 \\
\hline $\mathrm{SH}-2 / 25-\mathrm{AD}$ & 31 & $<5$ & 13 & 31 & 31 \\
\hline $\mathrm{SH}-2 / 26-\mathrm{AD}$ & 32 & $<5$ & 13 & 31 & 32 \\
\hline SH-2/27-AD & 35 & $<5$ & 15 & 52 & 35 \\
\hline
\end{tabular}


Appendix 8. Results of EDXRF analyses-Continued.

\begin{tabular}{cccccc}
\hline Sample & $\begin{array}{c}\mathbf{V} \\
\mathbf{p p m}\end{array}$ & $\begin{array}{c}\mathbf{W} \\
\mathbf{p p m}\end{array}$ & $\begin{array}{c}\mathbf{Y} \\
\mathbf{p p m}\end{array}$ & $\begin{array}{c}\text { Zn } \\
\mathbf{p p m}\end{array}$ & $\begin{array}{c}\mathbf{Z r} \\
\mathbf{p p m}\end{array}$ \\
\hline SH-2/28-AD & 43 & $<5$ & 25 & 36 & 43 \\
SH-2/29-AD & 52 & $<5$ & 26 & 40 & 52 \\
SH-2/30-AD & 38 & $<5$ & 16 & 36 & 38 \\
SH-2/31-AD & 54 & $<5$ & 28 & 44 & 54 \\
SH-2/32-AD & 140 & $<5$ & 35 & 112 & 140 \\
SH-2/33-AD & 105 & $<5$ & 34 & 59 & 105 \\
SH-2/34-AD & 99 & $<5$ & 36 & 107 & 99 \\
SH-2/35-AD & 61 & $<5$ & 37 & 43 & 61 \\
SH-2/36-AD & 85 & $<5$ & 33 & 97 & 85 \\
SH-2/37-AD & 43 & $<5$ & 25 & 36 & 43 \\
\hline
\end{tabular}


Appendix 9. Results of arsenic analyses by Hydride Generation Atomic Absorption Spectrophotometry (HGAAS) of air-dried sediment samples from the SH-2 borehole, Rajoir, Bangladesh.

[Zoe Ann Brown, USGS, Analyst; ppm, parts per million]

\begin{tabular}{cr}
\hline Sample & $\begin{array}{c}\text { As } \\
\text { (ppm) }\end{array}$ \\
\hline SH-2/1-AD & 3.9 \\
SH-2/2-AD & 2.5 \\
SH-2/3-AD & 4.2 \\
SH-2/4-AD & 1.9 \\
SH-2/5-AD & 1.3 \\
SH-2/6-AD & 1.2 \\
SH-2/7-AD & 1.2 \\
SH-2/8-AD & 2.7 \\
SH-2/9-AD & 11.0 \\
SH-2/10-AD & 1.6 \\
SH-2/11-AD & 1.1 \\
SH-2/12-AD & 1.5 \\
SH-2/13-AD & 0.8 \\
SH-2/14-AD & 0.7 \\
SH-2/15-AD & 4.8 \\
SH-2/16-AD & 1.0 \\
SH-2/17-AD & 0.7 \\
SH-2/18-AD & 1.1 \\
SH-2/19-AD & 0.7 \\
SH-2/20-AD & 0.6 \\
SH-2/21-AD & 0.6 \\
SH-2/22-AD & 0.8 \\
SH-2/23-AD & 2.4 \\
SH-2/24-AD & 1.0 \\
SH-2/25-AD & 1.8 \\
SH-2/26-AD & 0.9 \\
SH-2/27-AD & 0.9 \\
SH-2/28-AD & 1.1 \\
SH-2/29-AD & 0.8 \\
SH-2/30-AD & 0.7 \\
SH-2/31-AD & 0.6 \\
SH-2/32-AD & 6.5 \\
SH-2/33-AD & 5.1 \\
SH-2/34-AD & 21.0 \\
SH-2/35-AD & 0.6 \\
SH-2/36-AD & 1.2 \\
SH-2/37-AD & 8.1 \\
\hline & \\
\hline
\end{tabular}


Appendix 10. Total iron and ferrous iron extracted from preserved sediment samples from the SH-2 borehole, Rajoir, Bangladesh using a solution of $0.5 \mathrm{~N} \mathrm{HCl}$.

[Values calculated based on dry weight of the post-extraction residue; wt.\%, weight percent; Ferrous/Total Iron values $>1$ are within the $5 \%$ relative error]

\begin{tabular}{cccc}
\hline & $\begin{array}{c}\text { Total Iron } \\
\text { (wt. \%) }\end{array}$ & $\begin{array}{c}\text { Ferrous } \\
\text { (wt.\%) }\end{array}$ & Ferrous / Total Iron \\
\hline SH-2/1-P & 0.36 & 0.34 & 0.95 \\
SH-2/2-P & 0.65 & 0.59 & 0.92 \\
SH-2/3-P & 0.84 & 0.75 & 0.90 \\
SH-2/4-P & 0.36 & 0.32 & 0.89 \\
SH-2/5-P & 0.22 & 0.20 & 0.91 \\
SH-2/6-P & 0.40 & 0.37 & 0.91 \\
SH-2/7-P & 0.19 & 0.19 & 0.96 \\
SH-2/8-P & 0.29 & 0.26 & 0.89 \\
SH-2/9-P & 1.13 & 1.10 & 0.98 \\
SH-2/11-P & 0.13 & 0.12 & 0.92 \\
SH-2/12-P & 0.82 & 0.79 & 0.96 \\
SH-2/13-P & 0.66 & 0.63 & 0.95 \\
SH-2/14-P & 0.30 & 0.27 & 0.90 \\
SH-2/15-P & 0.63 & 0.60 & 0.96 \\
SH-2/16-P & 0.07 & 0.07 & 0.91 \\
SH-2/17-P & 0.32 & 0.29 & 0.93 \\
SH-2/18-P & 0.21 & 0.19 & 0.88 \\
SH-2/19-P & 0.24 & 0.22 & 0.93 \\
SH-2/20-P & 0.14 & 0.13 & 0.96 \\
SH-2/21-P & 0.10 & 0.09 & 0.95 \\
SH-2/22-P & 0.21 & 0.20 & 0.97 \\
SH-2/23-P & 0.82 & 0.73 & 0.90 \\
SH-2/24-P & 0.55 & 0.53 & 0.97 \\
SH-2/25-P & 0.62 & 0.60 & 0.97 \\
SH-2/26-P & 0.22 & 0.21 & 0.95 \\
SH-2/27-P & 0.20 & 0.19 & 0.96 \\
SH-2/28-P & 0.63 & 0.61 & 0.97 \\
SH-2/29-P & 0.11 & 0.10 & 0.98 \\
SH-2/30-P & 0.15 & 0.13 & 0.97 \\
SH-2/31-P & 0.13 & 0.12 & 0.93 \\
SH-2/32-P & 0.11 & 0.10 & 1.01 \\
SH-2/33-P & 1.02 & 1.03 & 1.03 \\
SH-2/34-P & 0.93 & 0.96 & 0.98 \\
SH-2/35-P & 0.13 & 0.14 & 0.10 \\
SH-2/36-P & 0.10 & 09 & \\
SH-2/37-P & 0.70 & & \\
\hline
\end{tabular}


Appendix 11. Results of analyses of $0.5 \mathrm{~N} \mathrm{HCl}$ extract solutions after reaction with preserved sediment samples from the SH-2 borehole Rajoir, Bangladesh. Concentrations determined by ICP-AES unless otherwise indicated.

[Paul Briggs and Z. A. Brown, USGS, Analyses; *, determined by HGAAS. Values calculated based on dry weight of the post-extraction residue; ppm, parts per million]

\begin{tabular}{|c|c|c|c|c|c|c|c|c|c|c|c|c|}
\hline Sample & $\begin{array}{c}\mathrm{Al} \\
\text { (ppm) }\end{array}$ & $\begin{array}{c}\text { As* } \\
\text { (ppm) }\end{array}$ & $\begin{array}{c}\text { B } \\
\text { (ppm) }\end{array}$ & $\begin{array}{c}\mathrm{Ba} \\
(\mathrm{ppm})\end{array}$ & $\begin{array}{c}\text { Be } \\
\text { (ppm) }\end{array}$ & $\begin{array}{c}\mathrm{Ca} \\
(\mathrm{ppm})\end{array}$ & $\begin{array}{c}\text { Cd } \\
\text { (ppm) }\end{array}$ & $\begin{array}{c}\text { Co } \\
\text { (ppm) }\end{array}$ & $\begin{array}{c}\mathrm{Cr} \\
(\mathrm{ppm})\end{array}$ & $\begin{array}{c}\text { Cu } \\
\text { (ppm) }\end{array}$ & $\begin{array}{c}\text { Fe } \\
(\mathrm{ppm})\end{array}$ & $\begin{array}{c}\mathrm{K} \\
\text { (ppm) }\end{array}$ \\
\hline $\mathrm{SH}-2 / 1-\mathrm{P}$ & 2600 & 1.0 & 2.7 & 20 & 0.4 & 1600 & 0.5 & 4.4 & 4.0 & 13 & 5600 & 580 \\
\hline $\mathrm{SH}-2 / 2-\mathrm{P}$ & 2600 & 0.2 & 0.9 & 23 & 0.2 & 3400 & $<0.2$ & 3.6 & 4.3 & 6 & 9500 & 380 \\
\hline $\mathrm{SH}-2 / 3-\mathrm{P}$ & 3300 & 1.5 & 1.6 & 44 & 0.4 & 3900 & 0.2 & 5.1 & 5.2 & 28 & 11,000 & 390 \\
\hline $\mathrm{SH}-2 / 4-\mathrm{P}$ & 1400 & 0.4 & 1.6 & 23 & 0.1 & 850 & $<0.2$ & 2.4 & 3.4 & 3 & 4800 & 270 \\
\hline $\mathrm{SH}-2 / 5-\mathrm{P}$ & 1100 & 0.2 & 0.8 & 16 & 0.1 & 840 & $<0.2$ & 1.7 & 1.9 & 2 & 3600 & 260 \\
\hline SH-2/6-P & 1600 & 0.2 & 0.6 & 28 & 0.2 & 900 & $<0.2$ & 2.4 & 2.8 & 4 & 5100 & 280 \\
\hline SH-2/7-P & 580 & 0.2 & 2.3 & 13 & 0.1 & 460 & $<0.2$ & 1.2 & 1.3 & 17 & 2500 & 160 \\
\hline $\mathrm{SH}-2 / 8-\mathrm{P}$ & 770 & 0.2 & 0.6 & 22 & 0.1 & 730 & $<0.2$ & 1.6 & 2.0 & 11 & 3700 & 190 \\
\hline SH-2/9-P & 570 & 0.7 & 1.9 & 140 & 0.8 & 2600 & 0.2 & 8.2 & 7.5 & 11 & 18,000 & 850 \\
\hline SH-2/11-P & 540 & 0.1 & 0.7 & 9 & 0.1 & 530 & $<0.2$ & 0.8 & 1.4 & 1 & 1400 & 160 \\
\hline SH-2/12-P & 2200 & 0.2 & 0.5 & 40 & 0.4 & 780 & $<0.2$ & 3.2 & 14.9 & 10 & 7800 & 520 \\
\hline SH-2/13-P & 1700 & $<0.1$ & 1.6 & 36 & 0.4 & 880 & $<0.2$ & 3.7 & 4.6 & 88 & 8600 & 530 \\
\hline SH-2/14-P & 930 & 0.1 & 2.5 & 19 & 0.1 & 820 & $<0.2$ & 1.5 & 3.0 & 31 & 3700 & 350 \\
\hline SH-2/15-P & 1300 & 0.7 & 1.1 & 38 & 0.6 & 1300 & $<0.2$ & 6.0 & 2.0 & 14 & 8400 & 320 \\
\hline SH-2/16-P & 330 & 0.1 & 0.4 & 6 & 0.1 & 260 & $<0.2$ & 1.1 & 1.4 & 1 & 950 & 95 \\
\hline SH-2/17-P & 180 & 0.1 & 0.8 & 22 & 0.3 & 980 & $<0.2$ & 4.8 & 4.3 & 33 & 4100 & 470 \\
\hline SH-2/18-P & 1100 & 0.2 & 1.3 & 17 & 0.1 & 1000 & $<0.2$ & 2.0 & 2.5 & 11 & 2700 & 340 \\
\hline SH-2/19-P & 1100 & 0.1 & 0.8 & 16 & 0.2 & 580 & $<0.2$ & 1.8 & 2.9 & 11 & 3200 & 320 \\
\hline SH-2/20-P & 640 & $<0.1$ & 1.2 & 9 & 0.1 & 560 & $<0.2$ & 1.4 & 1.5 & 1 & 1800 & 150 \\
\hline SH-2/21-P & 460 & $<0.1$ & 0.5 & 10 & 0.1 & 510 & $<0.2$ & 1.0 & 1.6 & 1 & 1400 & 110 \\
\hline SH-2/22-P & 740 & 0.1 & 0.6 & 10 & 0.1 & 640 & $<0.2$ & 1.9 & 3.3 & 2 & 2900 & 150 \\
\hline SH-2/23-P & 1100 & 6.2 & 0.6 & 37 & 0.4 & 1000 & 0.7 & 18 & 1.1 & 6 & 16,000 & 310 \\
\hline SH-2/24-P & 2700 & 0.2 & 1.5 & 28 & 0.4 & 970 & $<0.2$ & 8.3 & 4.9 & 4 & 7900 & 260 \\
\hline SH-2/25-P & 1500 & 0.5 & 0.9 & 21 & 0.3 & 950 & $<0.2$ & 3.2 & 2.9 & 3 & 8200 & 290 \\
\hline SH-2/26-P & 1000 & 0.1 & 1.0 & 20 & 0.2 & 890 & $<0.2$ & 1.8 & 2.7 & 2 & 2900 & 240 \\
\hline SH-2/27-P & 970 & 0.1 & 0.7 & 220 & 0.2 & 630 & $<0.2$ & 1.8 & 2.0 & 11 & 2700 & 290 \\
\hline
\end{tabular}


Appendix 11. Results of analyses of $0.5 \mathrm{~N} \mathrm{HCl}$ extract solutions-Continued

\begin{tabular}{|c|c|c|c|c|c|c|c|c|c|c|c|c|}
\hline Sample & $\begin{array}{c}\mathrm{Al} \\
(\mathrm{ppm})\end{array}$ & $\begin{array}{c}\text { As* } \\
\text { (ppm) }\end{array}$ & $\begin{array}{c}\text { B } \\
\text { (ppm) }\end{array}$ & $\begin{array}{c}\mathrm{Ba} \\
(\mathrm{ppm})\end{array}$ & $\begin{array}{c}\mathrm{Be} \\
(\mathrm{ppm})\end{array}$ & $\begin{array}{c}\mathrm{Ca} \\
(\mathrm{ppm})\end{array}$ & $\begin{array}{c}\mathbf{C d} \\
(\mathrm{ppm})\end{array}$ & $\begin{array}{c}\text { Co } \\
(\mathrm{ppm})\end{array}$ & $\begin{array}{c}\mathrm{Cr} \\
(\mathrm{ppm})\end{array}$ & $\begin{array}{c}\mathrm{Cu} \\
(\mathrm{ppm})\end{array}$ & $\begin{array}{c}\text { Fe } \\
\text { (ppm) }\end{array}$ & $\begin{array}{c}\mathrm{K} \\
\text { (ppm) }\end{array}$ \\
\hline SH-2/28-P & 990 & 0.1 & 1.0 & 40 & 0.2 & 750 & $<0.2$ & 2.3 & 1.7 & 20 & 8000 & 330 \\
\hline SH-2/29-P & 580 & 0.1 & 0.8 & 8 & 0.1 & 590 & $<0.2$ & 1.2 & 1.6 & 1 & 1500 & 150 \\
\hline SH-2/30-P & 630 & 0.1 & 1.1 & 200 & 0.2 & 620 & $<0.2$ & 1.4 & 1.0 & 16 & 2000 & 220 \\
\hline SH-2/31-P & 770 & 0.1 & 2.0 & 220 & 0.2 & 780 & $<0.2$ & 2.3 & 1.8 & 62 & 1800 & 290 \\
\hline $\mathrm{SH}-2 / 32-\mathrm{P}$ & 1200 & $<0.1$ & 1.8 & 110 & 0.7 & 3000 & $<0.2$ & 0.4 & 0.4 & 6 & 1600 & 280 \\
\hline SH-2/33-P & 1100 & 0.4 & 1.2 & 77 & 0.7 & 2900 & $<0.2$ & 4.1 & 0.7 & 21 & 13,000 & 180 \\
\hline SH-2/34-P & 3800 & 0.1 & 1.2 & 73 & 0.8 & 1600 & $<0.2$ & 4.5 & 7.7 & 21 & 13,000 & 320 \\
\hline SH-2/35-P & 530 & 0.8 & 1.1 & 9 & 0.1 & 1100 & $<0.2$ & 0.9 & 1.5 & 1 & 1900 & 150 \\
\hline SH-2/36-P & 500 & 0.1 & 0.7 & 27 & 0.1 & 730 & $<0.2$ & 1.4 & 1.6 & 1 & 1500 & 140 \\
\hline SH-2/37-P & 2100 & 0.2 & 1.3 & 36 & 0.5 & 1800 & $<0.2$ & 4.9 & 3.9 & 9 & 10,000 & 360 \\
\hline
\end{tabular}


Appendix 11. Results of analyses of $0.5 \mathrm{~N} \mathrm{HCl}$ extract solutions-Continued

\begin{tabular}{|c|c|c|c|c|c|c|c|c|c|c|}
\hline Sample & $\begin{array}{c}\mathbf{L i} \\
\text { (ppm) }\end{array}$ & $\begin{array}{c}\mathbf{M g} \\
(\mathrm{ppm})\end{array}$ & $\begin{array}{c}\mathbf{M n} \\
(\mathrm{ppm})\end{array}$ & $\begin{array}{c}\text { Mo } \\
\text { (ppm) }\end{array}$ & $\begin{array}{c}\mathrm{Na} \\
(\mathrm{ppm})\end{array}$ & $\begin{array}{c}\mathbf{N i} \\
(\mathrm{ppm})\end{array}$ & $\begin{array}{c}P \\
\text { (ppm) }\end{array}$ & $\begin{array}{c}\mathbf{P b} \\
(\mathrm{ppm})\end{array}$ & $\begin{array}{c}\text { Sb } \\
(\mathrm{ppm})\end{array}$ & $\begin{array}{r}\mathrm{SiO}_{2} \\
(\mathrm{ppm})\end{array}$ \\
\hline SH-2/1-P & 4.1 & 1900 & 64 & 0.33 & 96 & 11 & 360 & 8.0 & $<2$ & 3500 \\
\hline $\mathrm{SH}-2 / 2-\mathrm{P}$ & 4.3 & 2900 & 270 & 0.33 & 72 & 10 & 370 & 5.2 & $<2$ & 4000 \\
\hline $\mathrm{SH}-2 / 3-\mathrm{P}$ & 4.0 & 3900 & 440 & 0.31 & 280 & 13 & 480 & 13 & $<2$ & 5400 \\
\hline SH-2/4-P & 2.5 & 1000 & 75 & 0.29 & 210 & 8 & 270 & 3.3 & $<2$ & 2300 \\
\hline $\mathrm{SH}-2 / 5-\mathrm{P}$ & 2.1 & 710 & 66 & 0.33 & 130 & 6 & 320 & 2.6 & $<2$ & 1700 \\
\hline $\mathrm{SH}-2 / 6-\mathrm{P}$ & 2.9 & 1300 & 96 & 0.26 & 250 & 7 & 190 & 4.3 & $<2$ & 2300 \\
\hline SH-2/7-P & 1.0 & 340 & 39 & 0.26 & 180 & 3 & 200 & 2.4 & $<2$ & 970 \\
\hline $\mathrm{SH}-2 / 8-\mathrm{P}$ & 1.5 & 520 & 330 & 0.26 & 320 & 3 & 130 & 3.6 & $<2$ & 1200 \\
\hline $\mathrm{SH}-2 / 9-\mathrm{P}$ & 7.5 & 3800 & 120 & 0.33 & 950 & 18 & 320 & 23 & $<2$ & 4700 \\
\hline SH-2/11-P & 1.0 & 360 & 33 & 0.27 & 240 & 3 & 140 & 2.4 & $<2$ & 1000 \\
\hline SH-2/12-P & 2.2 & 1900 & 71 & 0.27 & 630 & 13 & 110 & 7.7 & $<2$ & 2900 \\
\hline SH-2/13-P & 1.8 & 1200 & 160 & 0.27 & 590 & 9 & 170 & 7.0 & $<2$ & 2300 \\
\hline SH-2/14-P & 1.5 & 690 & 57 & 0.26 & 700 & 4 & 180 & 3.8 & $<2$ & 1400 \\
\hline SH-2/15-P & 2.0 & 1300 & 340 & 0.29 & 1100 & 10 & 110 & 11 & $<2$ & 1800 \\
\hline SH-2/16-P & 0.4 & 240 & 7 & 0.28 & 100 & 2 & 35 & 2.0 & $<2$ & 730 \\
\hline SH-2/17-P & 2.2 & 1200 & 54 & 0.27 & 250 & 10 & 210 & 5.6 & $<2$ & 2500 \\
\hline SH-2/18-P & 1.6 & 700 & 47 & 0.27 & 260 & 5 & 310 & 3.7 & $<2$ & 2000 \\
\hline SH-2/19-P & 1.8 & 800 & 68 & 0.27 & 250 & 6 & 130 & 2.6 & $<2$ & 1600 \\
\hline SH-2/20-P & 1.0 & 580 & 34 & 0.26 & 170 & 4 & 110 & 2.3 & $<2$ & 1100 \\
\hline SH-2/21-P & 0.7 & 390 & 17 & 0.28 & 190 & 3 & 110 & 2.5 & $<2$ & 890 \\
\hline SH-2/22-P & 1.0 & 570 & 82 & 0.27 & 230 & 6 & 160 & 2.8 & $<2$ & 1300 \\
\hline SH-2/23-P & 1.5 & 860 & 970 & 0.27 & 230 & 39 & 230 & 26 & $<2$ & 1700 \\
\hline SH-2/24-P & 3.6 & 2200 & 160 & 0.29 & 360 & 17 & 160 & 5.9 & $<2$ & 2800 \\
\hline $\mathrm{SH}-2 / 25-\mathrm{P}$ & 2.0 & 1200 & 380 & 0.29 & 210 & 7 & 290 & 3.4 & $<2$ & 2200 \\
\hline SH-2/26-P & 1.3 & 810 & 46 & 0.27 & 170 & 6 & 290 & 2.9 & $<2$ & 1500 \\
\hline SH-2/27-P & 1.6 & 730 & 54 & 0.29 & 340 & 5 & 130 & 2.4 & $<2$ & 1800 \\
\hline
\end{tabular}


Appendix 11. Results of analyses of $0.5 \mathrm{~N} \mathrm{HCl}$ extract solutions-Continued

\begin{tabular}{|c|c|c|c|c|c|c|c|c|c|c|}
\hline Sample & $\begin{array}{c}\text { Li } \\
\text { (ppm) }\end{array}$ & $\begin{array}{c}\mathbf{M g} \\
\text { (ppm) }\end{array}$ & $\begin{array}{c}\mathrm{Mn} \\
\text { (ppm) }\end{array}$ & $\begin{array}{c}\text { Mo } \\
\text { (ppm) }\end{array}$ & $\begin{array}{c}\mathrm{Na} \\
\text { (ppm) }\end{array}$ & $\begin{array}{c}\mathrm{Ni} \\
\text { (ppm) }\end{array}$ & $\begin{array}{c}\mathbf{P} \\
\text { (ppm) }\end{array}$ & $\begin{array}{c}\mathbf{P b} \\
(\mathrm{ppm})\end{array}$ & $\begin{array}{c}\text { Sb } \\
(\mathrm{ppm})\end{array}$ & $\begin{array}{c}\mathrm{SiO}_{2} \\
\text { (ppm) }\end{array}$ \\
\hline SH-2/28-P & 1.6 & 740 & 570 & 0.3 & 270 & 4 & 200 & 4.0 & $<2$ & 1800 \\
\hline SH-2/29-P & 1.0 & 430 & 28 & 0.3 & 320 & 3 & 190 & 2.4 & $<2$ & 1200 \\
\hline SH-2/30-P & 1.1 & 450 & 61 & 0.3 & 300 & 3 & 150 & 3.0 & $<2$ & 1400 \\
\hline SH-2/31-P & 1.1 & 500 & 28 & 0.3 & 350 & 3 & 170 & 2.6 & $<2$ & 1700 \\
\hline SH-2/32-P & 1.2 & 1700 & 51 & 0.3 & 850 & 1 & 88 & 13 & $<2$ & 2100 \\
\hline SH-2/33-P & 0.9 & 1230 & 540 & 0.3 & 440 & 3 & 110 & 18 & $<2$ & 1900 \\
\hline SH-2/34-P & 3.5 & 2900 & 91 & 0.3 & 470 & 9 & 44 & 13 & $<2$ & 3700 \\
\hline $\mathrm{SH}-2 / 35-\mathrm{P}$ & 0.9 & 350 & 37 & 0.3 & 120 & 3 & 440 & 2.3 & $<2$ & 1100 \\
\hline SH-2/36-P & 0.9 & 330 & 23 & 0.3 & 150 & 3 & 260 & 1.6 & $<2$ & 960 \\
\hline SH-2/37-P & 3.6 & 1700 & 540 & 0.3 & 730 & 11 & 180 & 11 & $<2$ & 3200 \\
\hline
\end{tabular}


Appendix 11. Results of analyses of $0.5 \mathrm{~N} \mathrm{HCl}$ extract solutions-Continued

\begin{tabular}{|c|c|c|c|c|}
\hline Sample & $\begin{array}{c}\mathbf{S r} \\
\text { (ppm) }\end{array}$ & $\begin{array}{c}\mathrm{Ti} \\
\text { (ppm) }\end{array}$ & $\begin{array}{c}\mathbf{V} \\
\text { (ppm) }\end{array}$ & $\begin{array}{c}\mathrm{Zn} \\
\text { (ppm) }\end{array}$ \\
\hline SH-2/1-P & 10 & 54 & 14 & 32 \\
\hline SH-2/2-P & 8 & 170 & 7.1 & 19 \\
\hline $\mathrm{SH}-2 / 3-\mathrm{P}$ & 12 & 140 & 13 & 24 \\
\hline SH-2/4-P & 3 & 100 & 4.2 & 9 \\
\hline $\mathrm{SH}-2 / 5-\mathrm{P}$ & 3 & 73 & 3.0 & 8 \\
\hline $\mathrm{SH}-2 / 6-\mathrm{P}$ & 5 & 95 & 5.0 & 11 \\
\hline SH-2/7-P & 2 & 12 & 1.7 & 13 \\
\hline SH-2/8-P & 5 & 20 & 2.9 & 11 \\
\hline SH-2/9-P & 23 & $<1$ & 20 & 37 \\
\hline SH-2/11-P & 2 & 31 & 1.3 & 4 \\
\hline SH-2/12-P & 6 & 36 & 8.6 & 19 \\
\hline SH-2/13-P & 5 & $<1$ & 7.2 & 53 \\
\hline $\mathrm{SH}-2 / 14-\mathrm{P}$ & 5 & $<1$ & 2.7 & 27 \\
\hline $\mathrm{SH}-2 / 15-\mathrm{P}$ & 9 & $<1$ & 6.1 & 19 \\
\hline SH-2/16-P & 2 & 6 & 0.9 & 4 \\
\hline SH-2/17-P & 5 & 83 & 6.8 & 27 \\
\hline SH-2/18-P & 5 & 77 & 3.2 & 13 \\
\hline SH-2/19-P & 4 & 76 & 3.1 & 14 \\
\hline SH-2/20-P & 4 & 32 & 1.8 & 6 \\
\hline $\mathrm{SH}-2 / 21-\mathrm{P}$ & 3 & 17 & 1.5 & 4 \\
\hline SH-2/22-P & 3 & 55 & 2.6 & 7 \\
\hline $\mathrm{SH}-2 / 23-\mathrm{P}$ & 4 & 53 & 9.0 & 13 \\
\hline $\mathrm{SH}-2 / 24-\mathrm{P}$ & 6 & 150 & 8.8 & 22 \\
\hline SH-2/25-P & 3 & 150 & 7.2 & 13 \\
\hline SH-2/26-P & 4 & 92 & 3.3 & 8 \\
\hline SH-2/27-P & 10 & 62 & 2.2 & 15 \\
\hline
\end{tabular}


Appendix 11. Results of analyses of $0.5 \mathrm{~N} \mathrm{HCl}$ extract solutions-Continued

\begin{tabular}{crrrr}
\hline Sample & \multicolumn{1}{c}{$\begin{array}{c}\text { Sr } \\
\text { (ppm) }\end{array}$} & \multicolumn{1}{c}{$\begin{array}{c}\text { Ti } \\
\text { (ppm) }\end{array}$} & $\begin{array}{c}\text { V } \\
\text { (ppm) }\end{array}$ & \multicolumn{1}{c}{$\begin{array}{c}\text { Zn } \\
\text { (ppm) }\end{array}$} \\
\hline SH-2/28-P & 4 & 67 & 5.2 & 19 \\
SH-2/29-P & 2 & 25 & 1.8 & 5 \\
SH-2/30-P & 10 & 25 & 1.5 & 15 \\
SH-2/31-P & 12 & 12 & 1.6 & 45 \\
SH-2/32-P & 28 & $<1$ & 4.6 & 9 \\
SH-2/33-P & 17 & $<1$ & 5.9 & 15 \\
SH-2/34-P & 15 & 71 & 8.0 & 29 \\
SH-2/35-P & 3 & 29 & 1.5 & 5 \\
SH-2/36-P & 3 & 25 & 1.3 & 5 \\
SH-2/37-P & 13 & 9 & 4.6 & 20 \\
\hline
\end{tabular}


'Appendix 12. Concentrations of acid-volatile sulfide (AVS), reducible sulfide (DI), and acidsoluble sulfate $\left(\mathrm{SO}_{4}\right)$ in selected preserved sediment samples from the $\mathrm{SH}-2$ borehole, Rajoir, Bangladesh.

[ppm, parts per million]

\begin{tabular}{cccc}
\hline Sample & $\begin{array}{c}\text { Sulfide -AVS } \\
(\mathbf{p p m})\end{array}$ & $\begin{array}{c}\text { Sulfide -DI } \\
(\mathbf{p p m})\end{array}$ & $\begin{array}{c}\text { Acid-soluble-SO } \\
(\mathbf{p p m})\end{array}$ \\
\hline SH-2/1-P & 5250 & 9580 & 100 \\
SH-2/2-P & 390 & 350 & 50 \\
SH-2/3-P & 70 & 210 & 130 \\
SH-2/9-P & 80 & 214 & 60 \\
SH-2/15-P & 220 & 400 & 50 \\
SH-2/29-P & 10 & 30 & 50 \\
SH-2/34-P & 30 & 150 & 50 \\
SH-2/37-P & 20 & 300 & 30 \\
\hline
\end{tabular}

